\title{
Inhibitory Effect and Antimicrobial Activity of Secondary Metabolites of Khaya Senegalensis (Desr.) A. Juss. (Meliaceae)
}

\author{
Yves Oscar Ditchou Nganso ${ }^{1, ~ *, ~ E m m a n u e l l a ~ M a r t h e ~ S a t c h e t ~ T c h a n a ~}{ }^{2}$, Alex Doutsing Kahouo ${ }^{1}$, \\ Ange Gabrielle à Ngnoung Amang ${ }^{1}, K^{\prime}$ Komb Abah $^{1}$, Hermann Fomena ${ }^{1}$, Hamadou Mamoudou ${ }^{3,4}$ \\ ${ }^{1}$ Department of Chemistry, University of Maroua, Maroua, Cameroon \\ ${ }^{2}$ Department of Organic Chemistry, University of Yaoundé I, Yaoundé, Cameroon \\ ${ }^{3}$ Department of Biological Sciences, University of Maroua, Maroua, Cameroon \\ ${ }^{4}$ National Advanced School of Engineering of Maroua, University of Maroua, Maroua, Cameroon
}

Email address:

nganso_yves@yahoo.fr (Y. O. D. Nganso)

${ }^{*}$ Corresponding author

\section{To cite this article:}

Yves Oscar Ditchou Nganso, Emmanuella Marthe Satchet Tchana, Alex Doutsing Kahouo, Ange Gabrielle à Ngnoung Amang, Kombo Abah, Hermann Fomena, Hamadou Mamoudou. Inhibitory Effect and Antimicrobial Activity of Secondary Metabolites of Khaya Senegalensis (Desr.) A. Juss. (Meliaceae). Science Journal of Chemistry. Vol. 8, No. 4, 2020, pp. 81-94. doi: 10.11648/j.sjc.20200804.13

Received: August 3, 2020; Accepted: August 21, 2020; Published: September 17, 2020

\begin{abstract}
This present study investigates the in vitro inhibitory effect and antimicrobial activity of secondary metabolites isolated from the roots of Khaya senegalensis, a plant of the Meliaceae family. Khaya senegalensis is widely used in traditional medicine for the treatment of various illnesses such as: fever, stomach ache, diarrhea, dysentery and anemia. The chemical study of the extract with $\mathrm{CH}_{2} \mathrm{Cl}_{2}-\mathrm{MeOH}$ (1:1) led to the isolation of five compounds: Alphitolic acid (1); Epigouanic acid (2); Methyl angolensate (3); Rohituca-3 (4) and 5, 6, 7, 3', 4'-pentamethoxyflavone or Sinensetin (5). Alphitolic acid (1), Rohituca-3 (4) and 5, 6, 7, 3', 4'-pentamethoxyflavone or Sinensetin (5) were isolated from the roots of this plant for the first time. The structures of the isolated compounds have been elucidated on the basis of spectroscopic analysis and a comparison of their spectral data with those reported in the literature. The results of the antibiogram tests showed that the strain of Escherichia coli is sensitive to all the antibiotics tested except Ceftazidime, a Cephalosporin. The Staphylococcus aureus strain is resistant to almost all the antibiotics tested except Amikacin, an aminoglycoside. This is because the enzymes diffuse through the inter and intraspecific transmission of genes through a plasmid. The antibiogram made it possible to establish the sensitivity profile of the strains tested with regard to certain antibiotics. The antimicrobial tests carried out showed that the inhibitory effect of the compounds isolated from Khaya senegalensis on the four bacterial strains tested at the concentration of $25 \mathrm{mg} / \mathrm{mL}$ positively influenced at least one of the microbial strains. However, compounds 1, 2 and 3 did not show any bacterial growth inhibitory activity against Proteus vulgaris. MIC obtained for microbiological tests varied between 0.097 and $0.195 \mathrm{mg} / \mathrm{mL}$ for the most sensitive strains of Escherichia coli and Pseudomonas aeruginosa, which revealed the highest antibacterial powers. Furthermore, these results therefore show a great variability in the bacteriostatic qualities of the compounds with respect to the different strains. The two Grampositive strains of Staphylococcus aureus are more sensitive than the other Gram-negative bacterial strains tested. From the antibacterial activity, it appears that the compounds isolated from this plant have a bactericidal activity against Escherichia coli and Pseudomonas aeruginosa. This bactericide could justify their use in herbal medicine against bacterial infections.
\end{abstract}

Keywords: Inhibitory Effect, Antimicrobial Activity, Secondary Metabolites, Khaya Senegalensis, Meliaceae

\section{Introduction}

Enterobacteriaceae are Gram-negative bacilli belonging to the Enterobacteriaceae family. These bacteria are generally motile and facultative anaerobes [1, 2]. These bacteria are responsible for nosocomial infections, food poisoning, urinary tract infections, gastroenteritis, pneumonia and typhoid [2, 3]. Significant resistance has been observed for several bacteria which have spread in hospitals and 
communities [4]. These resistances are also noted in Enterobacteriaceae [5-7]. In Enterobacteriaceae, this resistance is due to the acquisition and dissemination of extended spectrum $\beta$-lactamases (ESBLs) [7, 8]. Some Enterobacteriaceae are resistant to almost all antibiotics, including the fourth generation Cephalosporins [5, 9]. These multidrug resistances are not only to genetic and environmental factors of the microorganism but also to the excessive and inappropriate use of antibiotics [10-12]. In Cameroon, at the Maroua Regional hospital in the Far North Region, multi-resistant bacteria are increasingly isolated (4 out of 10 germs). The spread of these bacteria poses a threat to public health because it makes it difficult to treat the infections associated with them [12]. The consequences of such resistance are associated with increased mortality, increased health care costs and the need to use more expensive drugs [12-14]. In view of this situation, the need of new, effective and affordable drugs to treat microbial diseases in developing countries is one of the challenges facing global health today [15]. In fact, the discovery of antibiotics reduced the spread and severity of a wide variety of diseases. However, due to their uncontrolled use, the effectiveness of many antibiotics is threatened by the development of microbial resistance to existing chemotherapeutic agents [16]. Bacteria and fungi develop many mechanisms to escape antimicrobial agents, and resistance to old and new antibiotics is increasing in medical practice [17]. In addition to small molecules derived from medicinal chemistry, natural products remain major sources of innovative therapeutic agents for various ailments, in particular infectious diseases [18]. Infectious agents are living beings (organisms belonging to one of the following 4 families: bacteria, viruses, parasites, microscopic fungi) or inanimate (toxins), called pathogens because they are likely to lead to infections or poisonings.

Faced with these problems, it is essential to search for new effective substances with a broad spectrum of action, which can fight against bacterial infections and attenuate or delay the oxidative process. Current research on molecules and natural products focuses mainly on plants because they can be obtained more easily and selected according to their ethno-medicinal use [19]. As an extension of this new drug discovery strategy, we studied the roots of Khaya senegalensis for their antimicrobial activities.

Khaya senegalensis commonly called Caïlcédrat or Senegalese mahogany in French and African mahogany in English or Jola in Cameroon and Dahlehi in Foulfoulde in the Far North Region of Cameroon, belongs to the Meliaceae family. It is an endemic species to many African countries [20]. It is a Tree that can reach up to $35 \mathrm{~m}$ tall and 60 to 100 $\mathrm{cm}$ in diameter and having a very thick trunk, is generally short and stocky, $2 \mathrm{~m}$ in diameter, sometimes with a low base, with a rounded crown and dense. Its leaves are arranged at the end of the twigs and form dense foliage [21]. Khaya senegalensis is widely used in traditional medicine for the treatment of various diseases such as: fever, stomach ache, diarrhea, dysentery and anemia, as an analgesic in cases of rheumatism and headaches, and as a tonic, emmenagogue and dewormer [22]. They are also used as a purgative, antidote and abortifacient, and to treat syphilis, leprosy, chickenpox and angina. Externally, the bark is applied as a disinfectant in cases of inflammation and to treat skin diseases, rashes, scabies, wounds, ulcers, boils, and hemorrhoids, edemas and toothaches [22]. Thus, Khaya senegalensis has undergone several screenings for its pharmacological properties in vitro and in vivo. In fact, previous pharmacological studies have shown that bark extracts are endowed with important antiplasmodial activities [23], as well as antibacterial activities [24, 25]. Previous chemical work carried out on Khaya senegalensis revealed that it does not contain an alkaloid [26, 27]. However, several authors report the presence of limonoids, polyphenols, tannins, coumarins and steroids [21-23]. Khaya senegalensis is a rich source of limonoids [28]. The use of Khaya senegalensis in the treatment of certain pathologies motivated our study in order to compare these traditional uses with scientific data. Thus, this study aims to determine the inhibitory potential in vitro and the antimicrobial activity of secondary metabolites isolated from the roots of Khaya senegalensis. This potential inhibitor in vitro is reported for the first time in this study.

\section{Materials and Methods}

\subsection{General Experimental Procedures}

After drying, crushing of the roots of Khaya senegalensis were carried out using a crushing machine. The maceration of the powder in Dichloromethane/Methanol was done in a tightly sealed $25 \mathrm{~L}$ can. An electronic scale of the HANGING SCALE Electronic type was used to measure the powdered mass of the crushed bark. A Buchi brand Heidolph WB 200 rotary evaporator was used for the evaporation and the condensation of the crude extract and the various fractions obtained. The flash chromatography was carried out using a VELP Scientifica vacuum cleaner, a micropore Buchner and a vacuum flask. The column chromatography was carried out in a column $2 \mathrm{~cm}$ in diameter and $40 \mathrm{~cm}$ in length and another $3 \mathrm{~cm}$ in diameter and $23 \mathrm{~cm}$ in length. KIESELGEL silica type $60(0.04-0.063 \mathrm{~mm})$ was used as stationary phase. All organic solvents used were of analytical grade and Fractions were monitored by TLC and performed on precoated silica gel 60 F254 plates (Merck, Dramstadt, Germany, This was done in the laboratory of the Institute for Environmental Research, Faculty of Chemistry). The spots were revealed using both ultra-violet light $(254 \mathrm{~nm}$ and $366 \mathrm{~nm}$ ) and $10 \% \mathrm{H}_{2} \mathrm{SO}_{4}$ spray reagent. The structures of isolated compounds were elucidated by means of spectroscopic experiments mainly 1D- and 2D NMR performed, on a 600 and $150 \mathrm{MHz}$ Bruker Avance III-600 spectrometer equipped with a $5 \mathrm{~mm} \mathrm{BBFO}^{+}$probe at $300 \mathrm{~K}$ and ESIMS/HRESIMS analyses recorded on a SYNAPT G2 HDMS (Waters) mass spectrometer and by comparison with literature data. A Shimadzu HPLC, model LC-6AD, equipped with a Shimadzu SPD-6AV UV detector (detection UV $\lambda 217$ and 254) and a Shodex Asahipak 
GS-310 2Ga column (460 × $25 \mathrm{~mm}, 10 \mu \mathrm{m}$ particle size) was used for the analysis. For the column chromatography, Silica gel 60 (Acros Organics) and Sephadex LH 20 (Amersham Pharmacia Biotech AB) were used.

\subsection{Plant Material}

The roots of Khaya senegalensis were collected on September 15, 2019 in Tchatibali in the Mayo-Danay Division in the Far North Region. The plant material was identified by $\mathrm{Dr}$ Froumsia Moskia Botanist of the Department of Biological Sciences of the University of Maroua. A voucher specimen has been deposited at the National Herbarium of Cameroon, Yaoundé under identification (reference number (56853/HNC)).

\subsection{Extraction and Isolation}

The roots $(2.0 \mathrm{~kg})$ of Khaya senegalensis were extracted by maceration with the mixture $\mathrm{CH}_{2} \mathrm{Cl}_{2}-\mathrm{MeOH}$ (1:1) (5 L x 2. $48 \mathrm{~h} /$ time) at room temperature. After filtration, the resulting solution was concentrated in vacuum to give 160.0 $\mathrm{g}$ of root bark extract. The root bark extract (150.0 g) was subjected to flash chromatography on silica gel $(800.0 \mathrm{~g}, 15 \mathrm{x}$ $30 \mathrm{~cm}$ ) with $n$-hexane-EtOAc mixtures (4:1 and $3: 1)$, EtOAc$\mathrm{MeOH}(1: 20)$ and $\mathrm{MeOH}$ and provided four fractions (K1, K2, K3 and K4) monitored by TLC. Fraction K2 (20.0 g) was subjected to silica gel column chromatography (70-230 mesh, $1.5 \times 90 \mathrm{~cm})$ using increasing polarity of the mixture of $n$ hexane-EtOAc (100:0 to 0:100) to give one hundred fractions of $150 \mathrm{~mL}$ each. Fractions of similar compounds were combined, based on their TLC profiles to give five sets (S1 (1-29), S2 (30-35), S3 (39-41), S4 (46-53), S5 (63-66), S6 (68-72), S7 (84-87) and S8 (90-100)). The S1 series, mainly an extract rich in weakly polar compounds, was subjected to column chromatography on silica gel (70-230 mesh, $1.5 \mathrm{x}$ $100 \mathrm{~cm}$ ) eluting with a gradient mixture of $n$-hexane-EtOAc of increasing polarity (100:0 to $0: 100)$ to lead to compound (1) (0.06 g) using $n$-hexane-EtOAc (19:1) as elution solvent. Compound (2) $(0.04 \mathrm{~g})$ was obtained from the S2 series by crystallization at room temperature followed by filtration. Series S3 (1.0 g) was further subjected to column chromatography $(20.0 \mathrm{~g}, 2 \times 90 \mathrm{~cm})$ on silica gel eluted with a mixture of $n$-hexane-EtOAc (4: 1, x 1 L) to give compound (5) $(0.025 \mathrm{~g})$. S4 $(3.0 \mathrm{~g})$ was purified by column chromatography on silica gel $(20.0 \mathrm{~g}, 2$ x $90 \mathrm{~cm})$ eluting successively with a gradient mixture of $n$-hexane-EtOAc (100:0 to $0: 100)$ to give compound (3) (0.05 g) using $n$ hexane-EtOAc (3:1) as eluent. From series 6, compound (4) $(0.02 \mathrm{~g})$ was obtained by crystallization at room temperature followed by filtration.

\subsection{Physical and Spectral Data of Compounds (1, 2, 3, 4 and 5)}

Alphitolic acid (1): Physical appearance: White powder; Molecular Formula: $\mathrm{C}_{30} \mathrm{H}_{48} \mathrm{O}_{4}$; Calculated mass: m/z: 472:

${ }^{1} \mathrm{H}$ NMR (600 MHz; DMSO-d6) $\delta 3.61$ (1H, ddd, H-2), $2.89(1 \mathrm{H}, \mathrm{d}, J=9.3, \mathrm{H}-3), 3.27$ (1H, ddd, $J=2.27, \mathrm{H}-13), 1.46$
(1H, t, J=11.3, H-18), 2.96 (1H, m, H-19), 1.01 (3H, s, H23), 0.92 (3H, s, H-24), 0.97 (3H, s, H-25), 0.99 (3H, s, H26), 4.71 (1H, d, $J=1.8, \mathrm{H}-29 \alpha), 1.70(3 \mathrm{H}, \mathrm{s}, \mathrm{H}-30)$,

${ }^{13} \mathrm{C}$ NMR (150 MHz; DMSO-d6) $\delta 48.60(\mathrm{C}-1), 69.90(\mathrm{C}-$ 2), 84.50 (C-3), 39.56 (C-4), 56.93 (C- 5), 19.62 (C-6), 35.56 (C-7), 42.11 (C-8), 52.10 (C-9), 39.77 (C-10), 22.35 (C-11), 26.97 (C-12), 39.62 (C-13), 43.77 (C-14), 31.92 (C-15), 33.49 (C-16), 57.64 (C-17), 50.57 (C-18), 48.53 (C-19), 152.08 (C-20), 30.89 (C-21), 38.24 (C-22), 29.24 (C-23), 17.34 (C-24), 17.99 (C-25), 16.74 (C- 26), 15.18 (C-27), 180.16 (C-28), 110.30 (C-29), 19.64 (C-30).

Epigouanic acid (2): Calculated mass of $\mathrm{C}_{29} \mathrm{H}_{46} \mathrm{O}$; $\mathrm{m} / \mathrm{z}=410 \mathrm{~g} / \mathrm{mol}$

${ }^{1} \mathrm{H}$ NMR (600 MHz, CD $\left.{ }_{3} \mathrm{OD}\right): \delta=\mathrm{H}-1$ (d, $\left.J=8 \mathrm{~Hz} ; 5.4\right)$;. H3 (d, $J=8 \mathrm{~Hz} ; 5.96)$; H-5 (dd, $J=4.66,9.23 \mathrm{~Hz} ; 1.14)$; H-9 (d, $J=11.41 \mathrm{~Hz} ; 1.88)$; H-13 (m, 2.41); H-18 (m, 1.69); H-19 (m, 3.3); H 23 (s, 1.04); H-24 (s, 0.91); H-25 (s, 0.98); H-26 (s, 1.07); Ha-29 (s, 4.58); Hb-29 (s, 4.52); H-30 (s, 1.70).

${ }^{13} \mathrm{C}$ NMR $\left(\mathrm{CD}_{3} \mathrm{OD}, 150 \mathrm{MHz}\right) \delta(\mathrm{ppm}): 44.89(\mathrm{C}-1), 63.35$ (C-2), 42.52 (C-3), 38.79 (C-4), 58.87 (C-5), 19.23 (C-6), 35.53 (C-7), 41.82 (C-8), 52.58 (C-9), 48.78 (C-10), 24.21 (C-11), 27.02 (C-12), 41.26 (C-13), 61.09 (C-14), 29.21 (C15), 38.25 (C-16), 57.29 (C-17), 52.98 (C-18), 48.68 (C-19), 151.54 (C-20), 31.55 (C-21), 38.55 (C-22), 34.20 (C-23), 27.06 (C-24), 19.65 (C-25), 18.31 (C-26), 180.14 (C-27), 179.26 (C-28), 110.56 (C-29), 20.40 (C-30).

Methyl angolensate (3): Calculated mass of $\mathrm{C}_{27} \mathrm{H}_{34} \mathrm{O}_{7}$; $\mathrm{m} / \mathrm{z}=470.2304 ; \mathrm{mp}: 110-111^{\circ} \mathrm{C}$

${ }^{1} \mathrm{H}$ NMR (600 MHz, $\left.\mathrm{CDCl}_{3}\right) \delta$ 7.48-7.38 (m, 25H), $7.28(\mathrm{~s}$, $4 \mathrm{H}), 7.13(\mathrm{~d}, J=10.2 \mathrm{~Hz}, 13 \mathrm{H}), 6.37$ (s, 13H), 5.87 (d, $J=10.2$ $\mathrm{Hz}, 13 \mathrm{H}), 5.62(\mathrm{~s}, 13 \mathrm{H}), 4.21-4.00(\mathrm{~m}, 3 \mathrm{H}), 3.93(\mathrm{~s}, 13 \mathrm{H})$, $3.60(\mathrm{~s}, 14 \mathrm{H}), 3.51(\mathrm{~s}, 3 \mathrm{H}), 2.61-2.42(\mathrm{~m}, 27 \mathrm{H}), 2.09-1.61$ (m, 82H), 1.61-1.44 (m, 48H), 1.40 (d, J=15.1 Hz, 2H), 1.33$1.18(\mathrm{~m}, 80 \mathrm{H}), 1.18-0.04(\mathrm{~m}, 131 \mathrm{H}), 0.92-0.04(\mathrm{~m}, 10 \mathrm{H})$.

${ }^{13} \mathrm{C}$ NMR (150 MHz, $\left.\mathrm{CDCl}_{3}\right) \delta 204.65$ (s), 168.35 (s), 157.83 (s), 142.97 (s), 141.16 (s), 125.75 (s), 120.60 (s), 109.96 (s), 78.47 (s), 77.18 (d, $J=23.4 \mathrm{~Hz}), 77.02$ (s), 76.77 (s), 70.03 (s), 69.69 (s), 57.81 (s), 44.53 (s), 44.17 (s), 43.63 (s), 40.18 (s), 38.32 (s), 37.91 (s), 27.30 (d, J=6.5 Hz), 26.34 (s), 21.51 (s), 19.96 (s), 18.69 (s), 17.76 (s), 15.01 (s).

Rohituca-3 (4): Calculated mass of $\mathrm{C}_{32} \mathrm{H}_{40} \mathrm{O}_{11} ; \mathrm{m} / \mathrm{z}=600$ $\mathrm{g} / \mathrm{mol}, \mathrm{m} / \mathrm{z}$ : $600.2571(100.0 \%)$.

${ }^{1} \mathrm{H}$ NMR $\left(600 \mathrm{MHz}, \mathrm{CDCl}_{3}\right) \delta(\mathrm{ppm}): 0.79(3 \mathrm{H}, \mathrm{s}) ; 0.83$ $(3 \mathrm{H}, \mathrm{t}, 7.5) ; 0.93(3 \mathrm{H}, \mathrm{d}, 6.5) ; 1.17(1 \mathrm{H}, \mathrm{m}) ; 1.25(3 \mathrm{H}, \mathrm{s})$; $1.33(1 \mathrm{H}, \mathrm{m}) ; 1.64(3 \mathrm{H}, \mathrm{s}) ; 1.66(1 \mathrm{H}, \mathrm{m}) ; 2.40(1 \mathrm{H}, \mathrm{m}) ; 2.44$ $(1 \mathrm{H}, \mathrm{t} ; 2.0) ; 2.72(1 \mathrm{H}, \mathrm{m}) ; 2.79(1 \mathrm{H}, \mathrm{m}) ; 2.80(1 \mathrm{H}, \mathrm{m}) ; 2.81$ $(1 \mathrm{H}, \mathrm{m}) ; 2.98(1 \mathrm{H}, \mathrm{t} ; 9.0) ; 3.22(1 \mathrm{H}, \mathrm{d} ; 10.0) ; 3.78(1 \mathrm{H}, \mathrm{d}$, $3.5) ; 3.99(1 \mathrm{H}, \mathrm{d}, 11.0) ; 3.99(1 \mathrm{H}, \mathrm{t} ; 3.0) ; 3.01(1 \mathrm{H}, \mathrm{m}) ; 4.22$ $(1 \mathrm{H}, \mathrm{t} ; 10.0) ; 4.24(1 \mathrm{H}, \mathrm{d}, 11.0) ; 5.35(1 \mathrm{H}, \mathrm{s}) ; 5.42(1 \mathrm{H}, \mathrm{s})$; $5.56(1 \mathrm{H}, \mathrm{d} ; 10.0) ; 6.10(1 \mathrm{H}, \mathrm{s}) ; 7.07(1 \mathrm{H}, \mathrm{s}) ; 7.32(1 \mathrm{H}, \mathrm{s})$.

${ }^{13} \mathrm{C}$ NMR (150 MHz, $\left.\mathrm{CDCl}_{3}\right) \delta(\mathrm{ppm}): 12,1(\mathrm{q}) ; 13,1(\mathrm{q})$; $15.1(\mathrm{q}) ; 16.9(\mathrm{q}) ; 24.2(\mathrm{t}) ; 24.2(\mathrm{t}) ; 26.9(\mathrm{q}), 31.4(\mathrm{t}) ; 31.4(\mathrm{t}) ;$ $35.1(\mathrm{~d}) ; 37.3(\mathrm{t}) ; 37.3(\mathrm{t}) ; 39.4(\mathrm{~d}) ; 42.1(\mathrm{t}) ; 42.1(\mathrm{t}) ; 43.9(\mathrm{~d}) ;$ $48.2(\mathrm{~s}) ; 51.8(\mathrm{~s}) ; 54.8(\mathrm{~d}) ; 72.0(\mathrm{t}) ; 72.0(\mathrm{t}) ; 74.5(\mathrm{~d}) ; 75.2$ (d); 78.7 (d); 79.3 (s); 79.7 (s); 79.8 (d); 110.6 (d); 121.5 (s); 122.7 (d); 122.7 (d); 138.9 (s); 140.0 (d); 143.3 (d); 167.7 (s); 171.3 (s); 175.4 (s); 209.1 (s). 
Sinensetin (5): Yellowish-white powder; ESI/MS: $\mathrm{m} / \mathrm{z}$ $375.1445[\mathrm{M}+\mathrm{H}]^{+}, \mathrm{C}_{20} \mathrm{H}_{20} \mathrm{O}_{7}$.

${ }^{1} \mathrm{H}$ NMR $\left(600 \mathrm{MHz}, \mathrm{CDCl}_{3}\right): \delta(\mathrm{ppm}): 7.00(1 \mathrm{H}, \mathrm{dd}$, $J=8.4,1.8 \mathrm{~Hz}, \mathrm{H}-6$ '), 6.99 (1H, d, $\left.J=1.8 \mathrm{~Hz}, \mathrm{H}-2^{\prime}\right), 6.90(1 \mathrm{H}$, d, $J=8.7 \mathrm{~Hz}, \mathrm{H}-5$ '), 6.35 (1H, s, H-8), 5.34 (1H, dd, $J=13.3$, $2.7 \mathrm{~Hz}, \mathrm{H}-2), 3.03(1 \mathrm{H}, \mathrm{dd}, J=16.7,13.4 \mathrm{~Hz}, \mathrm{H}-3 \mathrm{a}), 2.76$ $(1 \mathrm{H}, \mathrm{dd}, J=16.7,2.8 \mathrm{~Hz}, \mathrm{H}-3 \mathrm{~b}), 3.91(12 \mathrm{H}, \mathrm{m}, 4 \times \mathrm{OMe})$, $3.82(3 \mathrm{H}, \mathrm{s}, \mathrm{OMe})$;

${ }^{13} \mathrm{C}$ NMR (150MHz, $\left.\mathrm{CDCl}_{3}\right): \delta$ (ppm): 189.39 (C-4), 159.72 (C-9), 159.44 (C-7), 154.21 (C-5), 149.43 (C-4'), 149.24 (C-3'), 137.54 (C-6), 131.11 (C-1'), 118.83 (C-6'), 111.18 (C-5'), 109.40 (C-2'), 109.14 (C-10), 96.40 (C-8), 79.38 (C-2), 45.50 (C-3), 61.59, 61.30, 56.10, 55.97, 55.94 (5 $\times \mathrm{OMe})$.

\subsection{Biological Activities}

\subsubsection{Biological Material}

In this study, four bacterial strains were used, including 2 referenced strains and 2 strains provided by the Laboratory of the Medico-Social Center of the National Social Insurance Fund (NSIF) of Maroua. Among these strains, we have 3 Gram-negative (Escherichia coli ATCC 25922, Pseudomonas aeruginosa ATCC 10145, Proteus vulgaris) and 1 Grampositive (Staphylococcus aureus ATCC 25923). These strains were stored at $4{ }^{\circ} \mathrm{C}$ and were subcultured on the appropriate fresh agar plate 24 hour before doing any antimicrobial testing, in the Microbiology Laboratory of the Department of Biological Sciences of the Faculty of Science of the University of Maroua.

\subsubsection{Antibiogram}

The antibiogram was performed according to the recommendations of the CA-SFM [29]. The antibiotic discs used for this work are: Ceftazidine $30 \mu \mathrm{g}(\mathrm{CAZ})$, Ceftriaxone $10 \mu \mathrm{g}$ (CTR), Levofloxacin $5 \mu \mathrm{g}$ (LE), Gentamicin $10 \mu \mathrm{g}$ (GEN), Amikacin $30 \mu \mathrm{g}$ (AK), Ciprofloxacin $5 \mu \mathrm{g}$ (CIP) and Meropenem $10 \mu \mathrm{g}$ (MRP). For the various tests, we used a Gram-negative strain (Escherichia coli ATCC 25922) and a Gram-positive strain (Staphylococcus aureus ATCC 25923)

\subsubsection{Biological Study}

\section{i. Evaluation of the Antibacterial Activity}

The chloroform compounds with a mass of $1 \mathrm{~g}$ are dissolved in $1 \mu \mathrm{L}$ of dimethyl sulfoxide (DMSO) then $999 \mu \mathrm{L}$ of distilled water. The stock concentrations are prepared at the concentration of $1 \mathrm{mg} / \mathrm{mL}, 2 \mathrm{mg} / \mathrm{mL}$ and $4 \mathrm{mg} / \mathrm{mL}$ in DMSO except in the case of aqueous extracts where the stock concentrations are $4 \mathrm{mg} / \mathrm{mL}$ and $6 \mathrm{mg} / \mathrm{mL}$. They are filtered before any other use on millipore filters $(0.2 \mu \mathrm{m})$. Dilutions are then made in order to obtain the chosen concentrations. These concentrations are expressed in $\mathrm{mg} / \mathrm{mL}$.

\section{ii. Determination of the Inhibition Diameters (ID)}

The diameters of the inhibition zones were determined by the solid disc diffusion method using the well technique as described by Kiehbauch et al. [30]. An 18 to 24 hour bacterial suspension of each microbial strain is prepared with the nutrient broth (Diagnostic National Social Insurance Fund (NSIF), Maroua), diluted and adjusted to a turbidity equal to that of the Mc Farland 0.5 standard and the bacterial

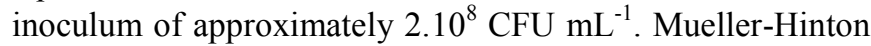
(MH) agar (Becton Dickinson USA) is poured into $90 \mathrm{~mm}$ diameter Petri dishes. The agar surface is seeded with $1 \mathrm{~mL}$ of mixture and then spread out the liquid in the Petri dish with Pasteur pipettes. Blotting paper discs $6 \mathrm{~mm}$ in diameter (Bio Mérieux) soaked with $70 \mu \mathrm{L}$ of compounds with a concentration of $1 \mathrm{mg} / \mathrm{mL}$ were placed on the surface of the agar. The dishes are then incubated at $37^{\circ} \mathrm{C}$ for 18 hours and the inhibition diameters are measured. After 18 to 24 hours of incubation, a clear area or halo is present around a disc if the compound inhibits microbial growth. The larger the inhibition zone, the more sensitive the germ. All the tests were repeated three times. The antimicrobial screening was carried out with 3 types of each compound and carried out 3 times.

\section{iii. Antibacterial Activity of the Compounds}

The antibacterial activity of the different compounds was evaluated by two methods:

1) Diffusion method in a solid medium

As described by Bauer et al. [31], and taken up by Ananil et al. [32]. From colonies that are 18 to 24 hours old, a bacterial suspension is made in sterile distilled water for each strain. The turbidity of this suspension is adjusted to $0.5 \mathrm{Mc}$ Farland then diluted to 1/100. An inoculum estimated at 106 colony-forming units per milliliter (Muc/mL) is then obtained. This inoculum is inoculated by flooding onto Petri dishes containing Mueller-Hinton agar [33]. Stock solutions concentrated at $25 \mathrm{mg} / \mathrm{mL}$ were prepared and are then sterilized in an autoclave $\left(121^{\circ} \mathrm{C}\right.$ for 15 minutes). Wattman blotting paper discs $6 \mathrm{~mm}$ in diameter are impregnated with $25 \mu \mathrm{L}$ of the stock solution. Disks are prepared impregnated with sterile distilled water and ethanol solvent (v/v). This last category of disc will serve as a negative control. Ampicillin discs $(10 \mu \mathrm{g})$ were also used as a reference antibiotic, positive control. The Petri dishes are first left for 1 hour at room temperature for pre-diffusion of the substances, before being incubated at $37^{\circ} \mathrm{C}$ in an oven for 24 hours. Antibacterial activity is determined by measuring the diameter of the zone of inhibition around each disc [34].

2) Method of diffusion in liquid medium: Determination of the Minimum Inhibitory Concentration (MIC):

For each compound, a sterile concentration range, ranging from 25 to $0.024 \mathrm{mg} / \mathrm{mL}$, with distilled water is prepared by the double dilution method. An inoculum is also prepared for each bacterial strain, the turbidity of which is adjusted to 0.5 Mc Farland (i.e. $10^{8} \mathrm{CFU} / \mathrm{mL}$ ) and brought to $10^{6} \mathrm{CFU} / \mathrm{mL}$ in two times concentrated Mueller Hinton broth. Then, $1 \mathrm{~mL}$ of each concentration and $1 \mathrm{~mL}$ of bacterial inoculum are added to hemolysis tubes. The concentration range of each extract is then diluted by half and spread out as follows: $25 ; 12.5 ; 6.25$; $3.125 ; 1.56 ; 0.78 ; 0.39 ; 0.195 ; 0.097 ; 0.048 ; 0.024 \mathrm{mg} / \mathrm{mL}$. A growth control tube is also prepared containing $1 \mathrm{~mL}$ of 
sterile distilled water and $1 \mathrm{~mL}$ of solvent. The seeded concentration range is incubated at $37^{\circ} \mathrm{C}$ for 24 hours. After incubation, bacterial growth is examined in each tube which results in turbidity. The MIC of compound for a given strain will be the smallest of the concentrations showing no visible growth of the germ [35].

\section{iv. Statistical Analyses}

The results were expressed as mean \pm SD. The one-way ANOVA test was used to compare results among and within groups for any significant difference in antibacterial activity of the compounds and the control.

\section{Results and Discussion}

The roots of Khaya senegalensis collected in Tchatibali in the Mayo-Danay Division in the Far-North Region of Cameroon in September 2019, were cut, dried, crushed and extracted with a $\mathrm{CH}_{2} \mathrm{Cl}_{2}-\mathrm{MeOH}$ mixture at room temperature. Several chromatographic techniques performed on this extract led to the isolation of five compounds (1-5) (Figure 1). The structures of the isolated compounds were established using spectroscopic analysis, in particular, the ${ }^{1} \mathrm{H}$ NMR, ${ }^{13} \mathrm{C}$ NMR spectra and two-dimensional NMR, COSY, HSQC, $\mathrm{HMBC}$ and direct comparison with the reference data from the available literature.

\subsection{Chemical Analysis}

Compound (1) was obtained in the form of a white powder in the $n$-hexane/EtOAc $20 \%$ system. The HR-ESI-MS mass spectrum of compound 1 carried out in positive mode shows a pseudo-molecular ion $[\mathrm{M}+\mathrm{Na}]^{+}$at $\mathrm{m} / \mathrm{z} \quad 954.3448$ corresponding to the crude formula $\mathrm{C}_{30} \mathrm{H}_{48} \mathrm{O}_{4}$. Analysis of its ${ }^{1} \mathrm{H}$ NMR spectrum, makes it possible to distinguish six singlet carbon atoms in the methyl region, each integrating $3 \mathrm{H}$ atoms corresponding to six methyl groups, one of which is deshielded towards $1.65 \mathrm{ppm}$ indicating a different electronic environment, two ethylenic protons resonating at 4.69 and at $4.56 \mathrm{ppm}$, three signals of intensity $1 \mathrm{H}$ at 3.59 ppm (td, $J=5.1-10.3 \mathrm{~Hz}), 2.95 \mathrm{ppm}(\mathrm{td}, J=4.9-10.7 \mathrm{~Hz})$ and $2.89 \mathrm{ppm}(\mathrm{d}, J=9.6 \mathrm{~Hz})$. By considering these observations, we suggest the presence of and/or electronegative elements and/or a double bond with neighboring protons. Analysis of the ${ }^{13} \mathrm{C} J$-modulated NMR spectrum of compound 1 reveals the presence of 30 carbons among which we can distinguish the following characteristic carbons: a mass of carbons between 14-50 ppm attributable to $\mathrm{CH}_{2}, \mathrm{CH}$ and $\mathrm{Cq}$ quaternary, an oxygenated carbon at $83.2 \mathrm{ppm}$, the two ethylenic carbons detected, including a quaternary carbon located at 150.6 and a methylenic carbon at $109.4 \mathrm{ppm}$, a carbonyl carbon at $179.1 \mathrm{ppm}$. By examining the COSY spectrum, we can identify two types of spectroscopic correlations: Descorrelations ${ }^{4} J_{1 \mathrm{H}-1 \mathrm{H}}$ (W-chain of allylic protons): long-distance coupling between the two germinal protons $\mathrm{Ha}, \mathrm{b}-29$ and the methyl protons $\mathrm{CH}_{3}-30{ }^{3} J_{1 \mathrm{H}-1 \mathrm{H}}$ correlations: proton H-19 exhibits three correlations, two of which are with the two germinal protons Ha, b-21 and the third belonging to the vicinal proton $\mathrm{H}-18$. The correlations of the two protons $\mathrm{Ha}, \mathrm{b}-21$ with the two protons $\mathrm{Ha}, \mathrm{b}-22$. A correlation between the vicinal protons $\mathrm{H}-18$ and $\mathrm{H}-13$. The proton resonating at $2.89 \mathrm{ppm}(\mathrm{d}, J=9.6 \mathrm{~Hz})$ correlates with that located at $3.59 \mathrm{ppm}(\mathrm{td}, J=10.3-5.1 \mathrm{~Hz})$, itself correlates with two germinal protons at $\delta_{\mathrm{H}} 0.79(\mathrm{t}, J=12.0 \mathrm{~Hz})$ and $\delta_{\mathrm{H}}$ 1.97 (dd, $J=12.4-4.6 \mathrm{~Hz}$ ). These four signals can be assigned to protons $\mathrm{H}-3, \mathrm{H}-2$ and $\mathrm{Ha}, \mathrm{b}-1$ respectively. The chemical shifts of protons $\mathrm{H}-2\left(\delta_{\mathrm{H}} 3.59\right)$ and $\mathrm{H}-3\left(\delta_{\mathrm{H}} 2.89\right)$ suggest that compound $\mathbf{1}$ is hydroxylated at the $\mathrm{C}-2$ and $\mathrm{C}-3$ positions. Thanks to the analysis of the direct heteronuclear correlations ${ }^{1} J_{\mathrm{H}-\mathrm{C}}$ observed on the HSQC $J$-modulated spectrum we can count 7 quaternary carbons, 7 methines, 10 methylenes and 6 methyls for compound 1. This analysis also allows us to identify the degree of substitution of the double bond deduced by the fact that the two ethylenic protons are carried by the same carbon (109.4 ppm) which confirms the presence of an isopropenyl exo-cyclic double bond $\left(\Delta^{20}\right)$. At this stage, all the spectral data obtained allows us to propose a pentacyclic triterpene skeleton derived from the lupane backbone. The analysis of its HMBC spectrum, shows the attribution of the $\mathrm{E}$ ring carbons of the triterpene: the protons of the methyl H-30 correlate with three carbons, including a quaternary carbon $\mathrm{C}-20$, a methylenic carbon $\mathrm{CH}_{2}-29$ and a methine carbon $\mathrm{CH}-19$ identified using the HSQC spectrum. At proton $\mathrm{H}-19$ we observe five correlations with the carbons C-18, C-20, C-21, C-29 and C-30. Proton H-18 ( $\delta \mathrm{C} \mathrm{1.54)}$ shows seven correlations of which three are with carbons already identified as C-19, C-20 and C-22, one with a tertiary carbon $\mathrm{CH}-13 \quad\left(\delta_{\mathrm{C}} 38.1\right)$, and three others with three quaternary carbons including a carbonyl $\left(\delta_{\mathrm{C}} \quad 179.1\right)$ identifiable as the $\mathrm{C}-28$ substituent and the C-14 and C-17 carbons $\left(\delta_{C} 42.4\right.$ and 56.2), respectively. The distinction between the two carbons $\mathrm{C}-14$ and $\mathrm{C}-17$ is made by the difference in chemical shift since $\mathrm{C}-17$ is the most deshielded $\left(\delta_{\mathrm{C}}\right.$ 56.2) under the effect of the adjacent carbonyl group. At the C-28 carbonyl, four correlations are demonstrated with the germinal protons $\mathrm{Ha}, \mathrm{b}-22$ already assigned and the two protons $\mathrm{Ha}, \mathrm{b}-16$. The $\mathrm{H}-13$ proton correlates with five carbons, four of which are already assigned the C-12, C-14, $\mathrm{C}-17$ and $\mathrm{C}-18$ carbons, the last one is easily attributed to the methyl carbon $\mathrm{C}-27$ ( $\delta \mathrm{C} 14.5$ ). The protons of methyl $\mathrm{CH}_{3}-$ 27 indicate the chemical shift of the methylenic carbon $\mathrm{CH}_{2}-$ $15\left(\delta_{\mathrm{C}} 29.6\right)$, and the quaternary carbon $\mathrm{C}-8\left(\delta_{\mathrm{C}} 40.7\right)$, thanks to two HMBC ${ }^{3} J_{\mathrm{H}-\mathrm{C}}$ correlations in addition to those with $\mathrm{C}$ 14 and C-13. All of these physical data and spectroscopic compared to those described in the literature made it possible to identify compound 1 with alphitolic acid [36, 37], isolated from the roots of Khaya senegalensis for the first time.

Compound (2) was obtained as a white solid, it melts between $210-212^{\circ} \mathrm{C}$, and showed a quasi-molecular ionic peak at $\mathrm{m} / \mathrm{z}=485.32744[\mathrm{M}-\mathrm{H}]^{-}$in the high resolution ESI mass spectrum, which in combination with ${ }^{13} \mathrm{C} N M R$ spectroscopic data provided the molecular formula $\mathrm{C}_{30} \mathrm{H}_{46} \mathrm{O}_{5}$. On its ${ }^{1} \mathrm{H}$ NMR spectrum, in combination with DEPT and HMQC spectra, showed five tertiary methyl groups, eleven methylene and six methane protons. Comfortable 
experiments revealed the presence of three spin systems in 2 . In the first system, methylene protons carrying oxygen at $\delta_{\mathrm{H}}=3.21 / 3.66 \quad(2 \mathrm{H}-2)$ showed coupling with methane hydrogen at $\delta_{\mathrm{H}}=1.82(\mathrm{H}-1)$, which in turn with two protons of methylene at $\delta_{\mathrm{H}}=1.78(2 \mathrm{H}-3)$. On the HMBC spectrum $\mathrm{H}-1$ and $\mathrm{H}-3$ showed correlations with a quaternary carbon at $\delta c=38.1(\mathrm{C}-4)$, and $\mathrm{H}-2$ showed a correlation with a tertiary carbon at $\delta \mathrm{c}=44.1(\mathrm{C}-1)$. This suggests a five-membered ring in structure 2 and a hydroxymethyl group attached to C-1. In the second spin system, we observed vicinal coupling between $\mathrm{H}-5 \quad\left(\delta_{\mathrm{H}}=1.19\right)$ and $2 \mathrm{H}-6\left(\delta_{\mathrm{H}}=1.37 / 1.43\right)$, which showed coupling with $2 \mathrm{H}-7\left(\delta_{\mathrm{H}}=2.07 / 2.43\right)$. In the third spin system, we observed a vicinal coupling between H-9
$\left(\delta_{\mathrm{H}}=1.79\right)$ and $2 \mathrm{H}-11\left(\delta_{\mathrm{H}}=1.35 / 1.54\right)$, and this with $2 \mathrm{H}-12$ $\left(\delta_{\mathrm{H}}=1.62 / 2.14\right)$, which showed a coupling with $\mathrm{H}-13$ $\left(\delta_{\mathrm{H}}=1.73\right)$. H-18 vicinal coupling exist with $\mathrm{H}-19\left(\delta_{\mathrm{H}}=3.11\right)$, which showed a coupling with $2 \mathrm{H}-21(\delta \mathrm{H}=1.91 / 1.98)$, and the latter with $2 \mathrm{H}-22 \quad\left(\delta_{\mathrm{H}}=1.51 / 1.66\right)$. This spin system unambiguously established the junction between rings $\mathrm{B}, \mathrm{C}$, $\mathrm{D}$ and structure 2. The unambiguous position of the substituents and unhydrogenated carbons of compound 2 was obtained using HMQC and HMBC spectra. These physical and spectroscopic data compared to those described in the literature made it possible to identify the compound (2) as being 2-hydroxy-2-nor-20 (29) lupen-27, 28-dioic acid and named Epigouanic acid. [38-40].

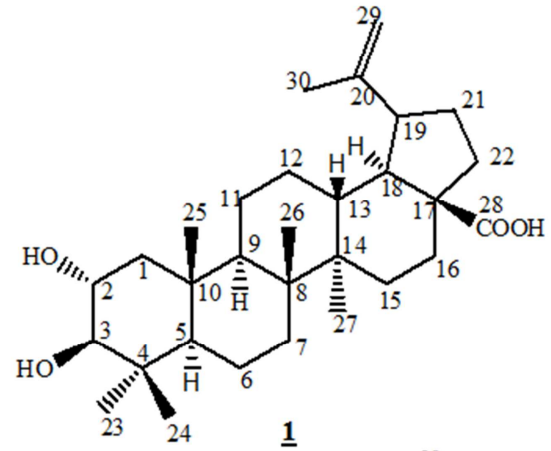

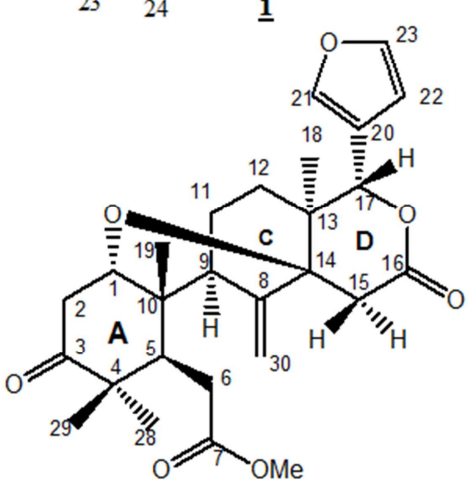

$\underline{\mathbf{3}}$

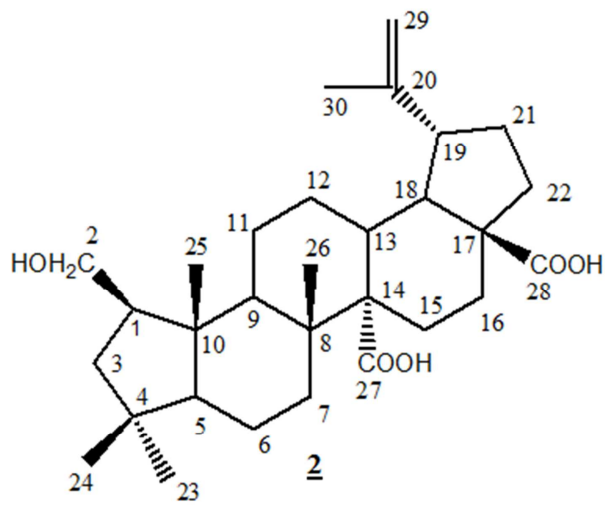

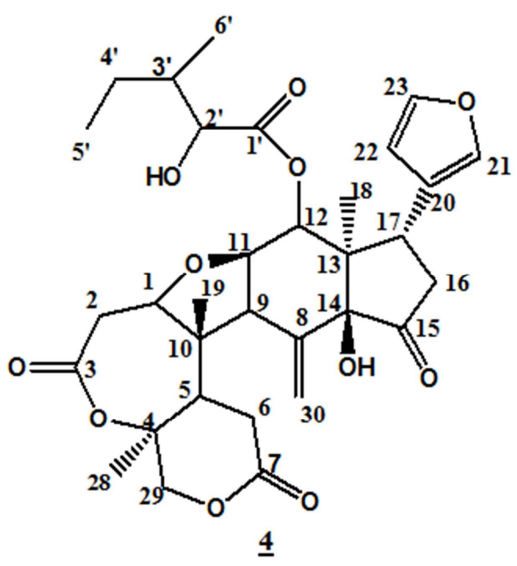<smiles>COc1ccc(-c2cc(=O)c3c(OC)c(OC)c(OC)cc3o2)cc1OC</smiles>

Figure 1. Structure of compounds 1 to 5 isolated from Khaya senegalensis.

Compound (3) crystallizes in the form of white crystals in a hexane-ethyl acetate mixture (80:20). Soluble in chloroform, it melts between $110-111^{\circ} \mathrm{C}$ and gives a positive reaction to both the Lieberman-Burchard test and the Erlich tests, thus suggesting its dual triterpene and limonoid nature. On its EI mass spectrum, the peaks of the molecular ion $[\mathrm{M}]^{+}$ 
are observed at $\mathrm{m} / \mathrm{z}=470.3$; and (calc. 470.2304 ) respectively allowing to give it the crude formula $\mathrm{C}_{27} \mathrm{H}_{34} \mathrm{O}_{7}$ containing 11 degrees of unsaturation. This high degree of unsaturation suggests the presence of several rings and multiple bonds in this compound. In addition to the molecular ion peak, we also observe on this spectrum the important fragment ions at $\mathrm{m} / \mathrm{z}$ 397,161 and 255. Its IR-TF spectrum shows vibration bands characteristic of $\mathrm{Csp}^{3}-\mathrm{H}$ bonds at $v_{\max } 2978 \mathrm{~cm}^{-1}$, ketone carbonyl at $v_{\max } 1736 \mathrm{~cm}^{-1}$ and $\mathrm{CO}$ ether linkages at $v_{\max }$ $1242 ; 1273$ and $1020 \mathrm{~cm}^{-1}$ respectively. On its ${ }^{13} \mathrm{C}$ NMR spectrum, 27 signals are observed corresponding to the 27 carbon atoms shown in the crude formula. The analysis of these signals using the DEPT 135 technique makes it possible to demonstrate the presence of: Six methylenes resonant between $\delta_{\mathrm{C}}$ 111.5-23.7 including an exo methylene hybridized in $\mathrm{sp}^{2}$ at $\delta_{\mathrm{C}} 111.5$, Five methylenes resonants between $\delta_{\mathrm{C}}$ 52.1-13.7 including a carbo methoxyl at $\delta_{\mathrm{C}} 52.1$, Seven resonant methines respectively at $\delta_{\mathrm{C}} 142.7 ; 140.7$; $109.9 ; 79.6 ; 77.2 ; 49.9$ and 42.9 , Nine quaternary carbons including 3 carbonyls (one ketone at $\delta \mathrm{c} 212.7$ and two esters at $\delta \mathrm{c} 173.8$ and 162.9); two $\mathrm{sp}^{2}$ carbons at $\delta \mathrm{c} 140.8$ and 120.8 and finally $4 \mathrm{sp}^{3}$ carbons at c $80.2 ; 48.1 ; 44.5$ and 41.4 , In weak fields, a set of signals consisting of 3 broad singlets of one proton each at $\delta_{\mathrm{H}} 7.41(1 \mathrm{H}, \mathrm{s}, \mathrm{H}-23) / \delta_{\mathrm{C}} 142.7 ; \delta_{\mathrm{H}} 7.36$ $(1 \mathrm{H}, \mathrm{s}, \mathrm{H}-21) / \delta_{\mathrm{C}} 140.2$ and $\delta_{\mathrm{H}} 6.36(1 \mathrm{H}, \mathrm{s}, \mathrm{H}-22) / \delta_{\mathrm{C}} 109.9$ characteristic respectively of the protons $\mathrm{H}-23, \mathrm{H}-21$ and $\mathrm{H}-$ 22 of a furan nucleus [41], In addition to the signals from the protons due to the furan nucleus, we also observe: A singlet of a proton at $\delta_{\mathrm{H}} 5.64 / \delta_{\mathrm{C}} 79.6$ characteristic of the $\mathrm{H} 17$ proton of the lactone ring of a limonoid [41]. Two singlets of one proton each at $\delta \mathrm{H} 5.13(1 \mathrm{H}, \mathrm{s}, \mathrm{H}-30) / \delta_{\mathrm{C}} 111.5 ; \delta_{\mathrm{H}} 4.88(1 \mathrm{H}, \mathrm{s}$, $\mathrm{H}-30) \delta_{\mathrm{C}} 111.5$ corresponding to the two olefinic protons of exomethylene in $\mathrm{C}-30$, Another singlet integrating 3 protons at $\delta_{\mathrm{H}} 3,69(1 \mathrm{H}, \mathrm{s}) / \delta_{\mathrm{C}} 52,1$ corroborating the presence of a carbomethoxyl (-COOMe), One multiplet of a proton at $\delta_{\mathrm{H}}$ $3.51(1 \mathrm{H}, \mathrm{m}, \mathrm{H}-1) / \delta_{\mathrm{C}} 80.1$ due to an oxymethyne, Two multiplets of a proton each at $\delta_{\mathrm{H}} 2.89 / \delta_{\mathrm{C}} 62.3$ and $2.85 / \delta_{\mathrm{C}}$ 61.5 corresponding to the two diastereotopic $\mathrm{H} 2$ protons, Two multiplets one at $\delta_{\mathrm{H}} 2.58 / \delta_{\mathrm{C}} 56.7$ and the other at $\delta_{\mathrm{H}} 2$, $52 / \delta_{\mathrm{C}} 54.2$ corresponding to the two diastereotopic protons in position 6 , A $3^{\text {rd }}$ pair of multiplets at $\delta_{\mathrm{H}} 2.46 / \delta_{\mathrm{C}} 39.4$ and $2.49 / \delta_{\mathrm{C}} 38.7$ attributable to the two diastereotopic protons at $\mathrm{C}-15$, Four singlets of three protons at $\delta_{\mathrm{H}} 1.17(3 \mathrm{H}, \mathrm{s}) ; 1.02$ $(3 \mathrm{H}, \mathrm{s},) ; 0.92(3 \mathrm{H}, \mathrm{s})$ and $0.84(3 \mathrm{H}, \mathrm{s})$ corresponding respectively to the angular methyls Me-29/ $\delta_{\mathrm{C}} 21.6 ; \mathrm{Me}-19 / \delta_{\mathrm{C}}$

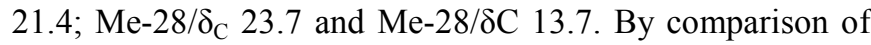
its spectral data with those described in the literature, the structure of compound 3 is identified with that of Methyl angolensate compound isolated for the first time from the fruits of Guarea kunthiana and exhibiting numerous biological activities: antiappetant, insecticide, anti-tumor against human cells (liver, kidney) [41, 42].

Compound (4) was obtained from root bark as white crystals in hexane-ethyl acetate $(3: 7)$. It melts between 174$176^{\circ} \mathrm{C}$ and gives a positive reaction to the Erhlich test, suggesting its limonoid nature. Its mass spectrum under ionization ESI-TOF shows the peak of the molecular ion at $\mathrm{m} / \mathrm{z} 600.6$ whose analysis at high resolution $\mathrm{m} / \mathrm{z} 600.6659$ allows it to be assigned the crude formula $\mathrm{C}_{32} \mathrm{H}_{40} \mathrm{O}_{11}$ (calc. 600,6678 ) containing thirteen (13) degrees of unsaturation. Its Fourier transform IR spectrum shows absorption bands of carbonyl group at $\left(v_{\max } 1744 \mathrm{~cm}^{-1}, 1710 \mathrm{~cm}^{-1}\right)$ and olefins at $v_{\max } 1636 \mathrm{~cm}^{-1}$. Its ${ }^{13} \mathrm{C}$ NMR proton decoupled broadband spectrum shows 32 signals corresponding to the 32 carbon atoms present in the molecule. Analysis of these signals using the DEPT technique and by interpretation of the HSQC spectrum reveals the presence of: Five methyl groups whose resonance signals appear at $\delta \mathrm{c} 12.1 ; 13.1$; 15.1; 16.9 and 26.9. Six methylenes including one $\mathrm{sp}^{2}$ hybrid resonating at $\delta c 122.7$ and the other five hybridized $\mathrm{sp}^{3}$ appearing at $\delta \mathrm{c} 72.0 ; 42.1 ; 37.3 ; 31.4$ and 24.2. The analysis of which is completed by both the COSY and HSQC spectra, makes it possible to demonstrate the presence of: Five methyls, three of which give signals in singlets, each integrating three protons at $\delta_{\mathrm{H}} 1.64(3 \mathrm{H}, \mathrm{s})$, $\delta_{\mathrm{H}} 1.25(3 \mathrm{H}, \mathrm{s})$ and $\delta_{\mathrm{H}} 0.79(3 \mathrm{H}, \mathrm{s})$ attributable to the angular methyls of a triterpene-like backbone, the two signals at $\delta_{\mathrm{H}} 0.83(3 \mathrm{H}, \mathrm{d}, 7.5) / \delta \mathrm{c} 12.1$ and at $\delta_{\mathrm{H}} 0.93(3 \mathrm{H}, \mathrm{t}$, $7.0) / \delta \mathrm{c} 14.9$, being attributed to the two methyl signals a unit of 2-hydroxy-3-methylvalerate, and a unit in which correlations appear between the proton $\mathrm{H}-2^{\prime}$ at $\delta_{\mathrm{H}} 3.78(1 \mathrm{H}$, $\mathrm{d}, 3.5)$ with the proton $\mathrm{H}-3^{\prime}$ at $\delta_{\mathrm{H}} 1.66(1 \mathrm{H}, \mathrm{m})$, which in turn correlates with the protons of methyl in position 3 ' to $\delta_{\mathrm{H}} 0.93(3 \mathrm{H}, \mathrm{d}, 7.0)$ on the one hand and with the protons in position $4^{\prime}$ to $\delta_{\mathrm{H}} 1.33(1 \mathrm{H}, \mathrm{m})$ and $\delta_{\mathrm{H}} 1.17(1 \mathrm{H}, \mathrm{m})$ on the other hand. We also observe on this spectrum: Three broad singlets of a proton each at $\delta \mathrm{H} 7.07(1 \mathrm{H}, \mathrm{s}), \delta \mathrm{H} 7.32(1 \mathrm{H}, \mathrm{s})$ and at $\delta_{\mathrm{H}} 6.10(1 \mathrm{H}, \mathrm{s})$ characteristic of a $\beta$-substituted furan ring in position $17 \alpha$ and whose presence is confirmed by the signals at $\delta$ c $143.2 ; 140.6$ and 110.6 observed on its ${ }^{13} \mathrm{C}$ NMR spectrum. Two large singlets of one proton each at $\delta_{\mathrm{H}}$ $5.35(1 \mathrm{H}, \mathrm{s}) / \delta \mathrm{c} 122.8$ and $\delta_{\mathrm{H}} 5.42(1 \mathrm{H}, \mathrm{s}) / \delta \mathrm{c} 122.8$ attributable to the protons of a terminal methylene in position 8 and characteristic of a limonoid skeleton of type B seco [43]. A signal at $\delta_{\mathrm{H}} 2.98(1 \mathrm{H}, \mathrm{t}, 9.0)$ typical of the proton in position $17 \beta$, and which presents on the COSY spectrum correlation spots with the 2 methylenic and diastereotopic protons in position 16 . The fact that the only correlations presented by the $\mathrm{H}-16$ protons are those with the $\mathrm{H}-17$ proton, leads us to position the resonant ketone carbonyl at $\delta \mathrm{c} 209.1$ in position 15. This was further confirmed by the HMBC correlations observed between the $\mathrm{H}-16$ proton and $\mathrm{C}-15$ carbon ( $\delta \mathrm{c} 209.1)$. In addition, the correlations observed between the olefinic protons $\mathrm{H}-30$ with the quaternary carbon $\mathrm{C}-14$ resonating at $\delta \mathrm{c} 79$, makes it possible to place the $\mathrm{OH}$ group on this carbon. All this is in accordance with the data of the literature, data according to which, the derivatives of the prieurianin 51 has within their structure either a 14-hydroxy-15 keto system or a 1415 epoxy ring [43]. Three multiplets of one proton each at $\delta \mathrm{H} 3.99(1 \mathrm{H}, \mathrm{t}, 3.0) / 78.7 ; 3.01(1 \mathrm{H}, \mathrm{m}) / 37.3$ and at $2.80(1 \mathrm{H}$, $\mathrm{m}) / 37.3$ attributable respectively to the $\mathrm{H}-1$ and $\mathrm{H}-2$ protons of a lactonized A ring, present in the compounds of the prieurianin class. Two AB systems of two diasteriotopic 
methylenic protons, one of which resonates in weak fields at $\delta_{\mathrm{H}} 4.24 ; 3.99(1 \mathrm{H}, \mathrm{d}, 11.0) / \delta \mathrm{c} 72.8$ and the other in strong fields at $2.79 ; 2.72(1 \mathrm{H}, \mathrm{m}) / \delta \mathrm{c} 31.4$ both show spots of HMBC correlations with the C-7 carbonyl at $\delta$ c 171.3 of a pyronne-type ring. All these spectral data are compatible with the presence in the structure of compound (4) of a prieurianin-type seco-limonoid A, B skeleton [43]. All that remained was to determine the position of the substituents on the limonoid backbone. This was made possible by the ${ }^{2} J$ and ${ }^{3} J$ correlations observed on the HMBC spectrum of this compound. Indeed, the 2-hydroxy-3-methylvalerate group was localized in position $\mathrm{C}-12$ thanks to the HMBC correlations observed between the proton $\mathrm{H}-12$ at $\delta_{\mathrm{H}} 5.87$ $(1 \mathrm{H}, \mathrm{d}, 10)$ and the carbon $\mathrm{C}-1^{\prime}$ at $\delta \mathrm{c} 175.4$. The ether junction between the $\mathrm{C}-1$ and $\mathrm{C}-11$ carbons has been established on the basis of biogenetic considerations and data from the literature [43]. As for the relative stereochemistry around the carbons, C-1, C-11 and C-12, they were established on the basis of the ${ }^{3} \mathrm{~J}$ coupling constants, observed between the protons carried by these different carbons and confirmed by the data in the literature.

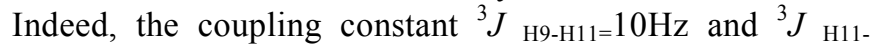
${ }_{\mathrm{H} 12}=10 \mathrm{~Hz}$ suggests that the protons $\mathrm{H}-9$ and $\mathrm{H}-11$ on the one hand, and the protons $\mathrm{H}-11$ and $\mathrm{H}-12$, on the other have relative trans stereochemistry. On the basis of all these data in comparison with those of the literature, the compound (4) was identified as Rohituka-3. Isolated for the first time from the roots of Khaya senegalensis, by Gunatilaka et al. [44] and whose spectral data correspond well to those we have had obtained.

Compound (5): crystallizes in the form of a white powder; It melts between $320-321^{\circ} \mathrm{C}$ and reacts positively to Molish's test, suggesting that it is a flavonoid. Its electron impact mass spectrum shows the peak of the molecular ion at $[\mathrm{M}]^{+} \mathrm{m} / \mathrm{z}$
375.1445, giving it the crude formula $\mathrm{C}_{20} \mathrm{H}_{20} \mathrm{O}_{7}$ containing 11 degrees of unsaturation. Its IR-TF spectrum shows an absorption band at $v_{\max } 1670 \mathrm{~cm}^{-1}$ indicating the presence in the compound of a carbonyl group. Likewise, the absorption bands at $v_{\max } 2900$ and 1480 are observed, indicating the presence of the $\mathrm{C}-\mathrm{H}$ and $\mathrm{C}=\mathrm{C}$ groups respectively. Analysis of its ${ }^{1} \mathrm{H}$ NMR spectrum shows: A system of three aromatic protons $\mathrm{ABX}$ resonating at $\delta_{\mathrm{H}} 7.88(1 \mathrm{H}, \mathrm{dd}, J=9.0$ and 2.0 $\mathrm{Hz}), 7.05(1 \mathrm{H}, \mathrm{d}, J=9,0 \mathrm{~Hz})$ and $7.69(1 \mathrm{H}, \mathrm{d}, J=2.0)$ corresponding to H-6 ', H-5' and H-2 'and compatible with an aromatic nucleus substituted with an isoflavone [45]. Two protons in singlet form each resonating at $\delta_{\mathrm{H}} 6.44(1 \mathrm{H}, \mathrm{d}, J=2$ $\mathrm{Hz})$ and $6.34(1 \mathrm{H}, \mathrm{d}, J=2 \mathrm{~Hz})$ attributable respectively to the meta H- 6 and H- 8 protons of the trisubstituted A ring, Three signals of three protons each as a singlet at $\delta \mathrm{H} 3.96(3 \mathrm{H}, \mathrm{s})$; $3.86(3 \mathrm{H}, \mathrm{s})$ and $3.84(3 \mathrm{H}, \mathrm{s})$ attributable to the methoxyls OMe-7, OMe-4' and OMe-3, respectively. Based on all these data and by comparison with those described in the literature, the structure of compound (5) has been attributed to 5, 6, 7, 3', 4'-pentamethoxyflavone or Sinensetin. Isolated for the first time from roots of Khaya senegalensis and previously roots of Citrus reticulata $[46,47]$.

\subsection{Antibiogram Carried out on a Gram- and Gram + Strains}

The CA-SFM manual [29] was used for the interpretive reading of the inhibition diameters. The various antibiotics in (Table 1) are grouped into three classes: $\beta$-lactam (Ceftazidine, Ceftriaxone, Meropenem), quinolones (Levofloxacin, Ciprofloxacin) and aminoglycosides (Gentamicin, Amikacin). For the different tests, we used a Gram-negative strain (Escherichia coli) and a Gram-positive strain (Staphylococcus aureus)

Table 1. Antibiogram Results.

\begin{tabular}{|c|c|c|c|c|c|}
\hline \multirow{2}{*}{ Bacterial strains } & \multirow{2}{*}{ Antibiotics } & \multirow{2}{*}{$\mathbf{D}(\mathbf{m m})$} & \multicolumn{3}{|c|}{ Sensitivity } \\
\hline & & & $\mathrm{S} \geq *$ & $\mathbf{R}<*$ & Observations \\
\hline \multirow{7}{*}{ Escherichia coli } & Ceftazidime & 19 & 22 & 19 & I \\
\hline & Ceftriaxone & 30 & 25 & 22 & $\mathrm{~S}$ \\
\hline & Gentamicine & 21 & 17 & 14 & $\mathrm{~S}$ \\
\hline & Amikacine & 21 & 16 & 13 & $\mathrm{~S}$ \\
\hline & Levofloxacine & 30 & 23 & 19 & $\mathrm{~S}$ \\
\hline & Ciprofloxacine & 28 & 26 & 24 & $\mathrm{~S}$ \\
\hline & Meropenem & 30 & 22 & 16 & $\mathrm{~S}$ \\
\hline \multirow{7}{*}{ Staphylococcus aureus } & Ceftazidime & 10 & 22 & 19 & $\mathrm{R}$ \\
\hline & Ceftriaxone & 24 & 25 & 22 & I \\
\hline & Gentamicine & 16 & 17 & 14 & I \\
\hline & Amikacine & 21 & 16 & 13 & $\mathrm{~S}$ \\
\hline & Levofloxacine & 15 & 23 & 19 & $\mathrm{R}$ \\
\hline & Ciprofloxacine & 23 & 26 & 24 & $\mathrm{R}$ \\
\hline & Meropenem & 16 & 22 & 16 & I \\
\hline
\end{tabular}

*Reference values provided by the CA-SFM manual; S: Sensitive; R: Resistant; I: Intermediate $\geq$ : upper; <: lower.

The results in Table 1 show that the strain of Escherichia coli is sensitive to all the antibiotics tested except Ceftazidime, a cephalosporin. The Staphylococcus aureus strain is resistant to almost all of the antibiotics tested except Amikacin, an aminoglycoside. These observations show that
Escherichia coli is sensitive to almost all the antibiotics tested except to Ceftazidime in which intermediate resistance is observed. Ceftazidime is a $3^{\text {rd }}$ generation cephalosporin [48]. The resistance of this bacterium is explained by its belonging to the class 1 enterobacterium. Class which is 
characterized by a natural resistance of bacteria to cephalosporins through the production of a low-level cephalosporinase [49]. This enzyme hydrolyzes penicillins, $1^{\text {st }}$ generation cephalosporins and in rare cases $3^{\text {rd }}$ generation cephalosporins. It is, however, difficult to detect phenotypically and is expressed by a decrease in MIC [48, 49]. The strain of Staphylococcus aureus exhibits a different susceptibility profile despite belonging to class 1 enterobacteriaceae. This strain developed resistance to the $\beta$ lactam antibiotics tested (Ceftazidine, Ceftriaxone, Meropenem) as well as quinolones (Levofloxacin, Ciprofloxacin) and intermediate sensitivity to Gentamicin and total sensitivity to Amikacin. This acquired resistance of Staphylococcus aureus can be justified by mutations conditioned by the excessive and inappropriate use of antibiotics $[10,12,50]$. This resistance profile observed in Staphylococcus aureus is increasingly present in hospitals and often leads to therapeutic impasses and high mortality. This phenomenon is all the more worrying as these enzymes diffuse very quickly throughout the world via the movements of living beings, and plants used as food but also through the inter and intraspecific transmission of genes by means of a plasmid [51].

\subsection{Results of Antibacterial Activity}

The evaluation of the antimicrobial activity of the compounds was made by measuring the diameter of the zone of inhibition around the wells. The objective of this work is to determine among the compounds prepared those which had the greatest inhibitory activity of Gram-positive bacteria, Gramnegative bacteria. For each plant species and within the same species, the nature of the phytochemical components is at the origin of the biological activities of each extract or fraction. These activities are also dependent on the content of the substance or all of the biologically active substances. The results obtained revealed a notable antibacterial activity of the compounds of PPI (1), MUV (2), AHA (3), CONT (4) and AMPT (5) against the bacteria tested.

\subsubsection{Antibacterial Activity of the Compounds on Staphylococuss aureus}

The different compounds were tested on Staphylococcus aureus and the results are given in Table 2 below.

Table 2. Inhibitory effect of compounds on the culture of Staphylococcus aureus (expressed in diameter of inhibition of bacterial growth $+/$ - standard deviation).

\begin{tabular}{|c|c|c|c|c|}
\hline \multirow{2}{*}{ Compounds } & \multicolumn{4}{|c|}{ Staphylococcus aureus } \\
\hline & D1 (mm) & D2 (mm) & D3 (mm) & Mean \pm SD \\
\hline PPI (1)" & 15 & 10 & 12 & $12.33 \pm 2.52^{\mathrm{DDA}}$ \\
\hline MUV (2) • & 17 & 15 & 18 & $16.66 \pm 1.53^{\mathrm{DOD} A}$ \\
\hline AHA (3) • & 10 & 15 & 16 & $13.66 \pm 3.21^{\mathrm{DaA}}$ \\
\hline CONT (4) & 0 & 0 & 0 & $0 \pm 0$ \\
\hline $\operatorname{AMPIC~(5)\bullet ~}$ & 32 & 32 & 32 & $32 \pm 0$ \\
\hline
\end{tabular}

PPI (1)=Alphitolic acid, MUV (2)=Epigouanic acid, AHA (3)=Methyl angolensate, CONT (4)=Rohituca-3, AMPI (5)=Sinensetin, D 1, 2 and 3: Diameter of inhibition measured, Avg: Average of three repetitions of inhibition diameter, SD: Standard deviation, $\mathbf{\square}: 200 \mu \mathrm{g} / \mathrm{mL}, \mathbf{*} 10 \mu \mathrm{g} / \mathrm{disc}$, $\mathrm{axP}<0.05)$ [compounds vs control], the values marked with the letter $\mathrm{A}$ are not significantly different.

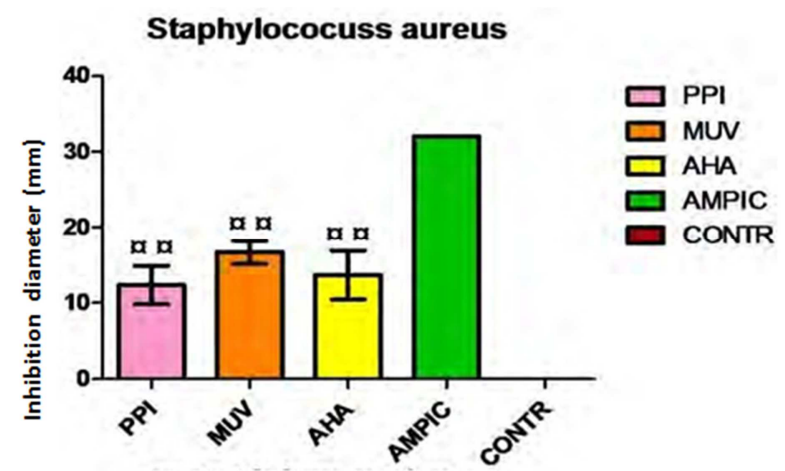

Figure 2. Antimicrobial activity of compounds on Staphylococuss aureus.

At a concentration of $25 \mathrm{mg} / \mathrm{mL}$ the compounds PPI (1)=Alphitolic acid, MUV (2)=Epigouanic acid, AHA (3)=Methyl angolensate and AMPI (5)=Sinensetin at 10 $\mu \mathrm{g} /$ disc have a significant effect on the Staphylococcus aureus strain tested against the control. In the presence of the compounds PPI (1)=Alphitolic acid $(\mathrm{P}<0.05)$, MUV (2)=Epigouanic acid $(\mathrm{P}<0.05)$ and AHA $(3)=$ Methyl angolensate $(\mathrm{P}<0.05)$ Staphylococcus aureus has developed diameters of inhibition of 12.33, 16.66 and $13.66 \mathrm{~mm}$ respectively (Figure 2). No significant difference between the compounds of PPI (1)=Alphitolic acid, MUV (2)=Epigouanic acid and AHA (3)=Methyl angolensate.

\subsubsection{Antibacterial Activity of the Compounds on Escherichia coli}

The different compounds were tested on Escherichia coli and the results are shown in Table 3 below.

Table 3. Inhibitory effect of the compounds on the culture of Escherichia coli.

\begin{tabular}{|c|c|c|c|c|c|}
\hline \multirow{2}{*}{ Compounds } & \multicolumn{4}{|c|}{ Escherichia coli } & \multirow{2}{*}{ CMI (mg/mL) } \\
\hline & D1 (mm) & D2 (mm) & D3 (mm) & Mean \pm SD & \\
\hline PPI (1)" & 18 & 11 & 14 & $14.33 \pm 3.51^{\mathrm{a}} \downarrow \downarrow$ & 0.195 \\
\hline $\operatorname{MUV}(2)$ • & 13 & 16 & 17 & $15.33 \pm 2.08^{\mathrm{ax}[[}$ & 0.195 \\
\hline $\mathrm{AHA} \mathrm{(3)} \mathrm{•}$ & 9 & 6 & 7 & $7.33 \pm 1.53^{a \mathrm{ac}_{\mathrm{c}}}$ & \\
\hline CONT (4) & 0 & 0 & 0 & $0 \pm 0$ & \\
\hline AMPIC (5) & 25 & 25 & 25 & $25 \pm 0$ & \\
\hline
\end{tabular}

PPI (1)=Alphitolic acid, MUV (2)=Epigouanic acid, AHA (3)=Methyl angolensate, CONT (4)=Rohituca-3, AMPI (5)=Sinensetin, D 1, 2 and 3: Diameter of inhibition measured, Avg: Average of three repetitions of inhibition diameter, SD: Standard deviation, MIC: Minimum Inhibition Concentration, $\mathbf{~ : ~ 2 0 0 ~}$ $\mu \mathrm{g} / \mathrm{mL}, \bullet: 10 \mu \mathrm{g} / \mathrm{disc}, \mathrm{a} \propto \mathrm{P}<0.05)$ [compounds vs control], $(\mathrm{P}<0.01)$ [Compound 1 vs 3], [[( $<<0.01)$ [compound 2 vs 3], values with the letter $\mathrm{C}$ are not significantly different. 
At a concentration of $25 \mathrm{mg} / \mathrm{mL}$, the compounds PPI (1)=Alphitolic acid, MUV (2)=Epigouanic acid, AHA (3)=Methyl angolensate and CONT (4)=Rohituca-3 at 10 $\mu \mathrm{g} / \mathrm{disc}$ have a significant effect on the strain of Escherichia coli tested compared to the control. In the presence of the compounds of PPI $(1)=$ Alphitolic acid $(\mathrm{P}<0.05)$, MUV (2)=Epigouanic acid (P <0.05) and AHA (3)=Methyl angolensate $(\mathrm{P}<0.05)$ Escherichia coli has developed diameters inhibition within 24 hours of 14.33, 15.33 and 7.33 $\mathrm{mm}$ respectively (Figure 3 ). A significant difference of the compound PPI $(1)=$ Alphitolic acid $(\mathrm{P}<0.01)$ compared to the compound MUV (2)=Epigouanic acid and a significant difference of the compounds MUV (2)=Epigouanic acid ( $\mathrm{P}$ $<0.01)$ compared to the compound AHA (3)=Methyl angolensate, on the other hand no significant difference between the compounds PPI (1)=Alphitolic acid and MUV (2)=Epigouanic acid.

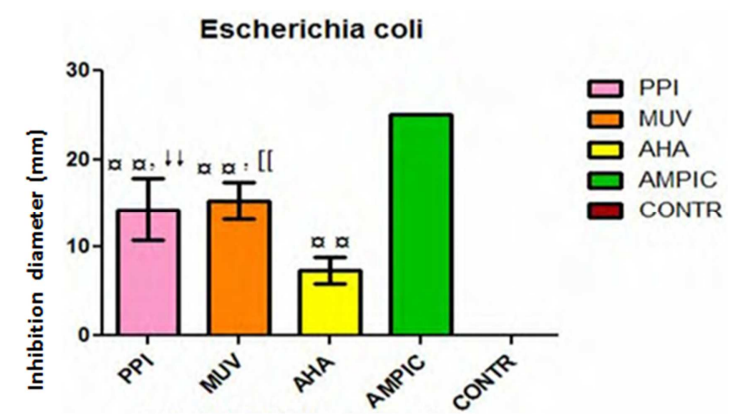

Figure 3. Antimicrobial activity of the compounds on Escherichia coli.

\subsubsection{Antibacterial Activity of the Compounds on Pseudomonas aeruginosa}

The different compounds were tested on Pseudomonas aeruginosa and the results are given in Table 4 below.

Table 4. Inhibitory effect of the compounds on the culture of Pseudomonas aeruginosa (expressed in diameter of inhibition of bacterial growth +/standard deviation)

\begin{tabular}{|c|c|c|c|c|c|}
\hline \multirow[b]{2}{*}{ Compounds } & \multicolumn{4}{|c|}{ Pseudomonas aeruginosa } & \multirow{2}{*}{$\begin{array}{l}\text { CMI } \\
(\mathrm{mg} / \mathrm{mL})\end{array}$} \\
\hline & $\begin{array}{l}\text { D1 } \\
(\mathrm{mm})\end{array}$ & $\begin{array}{l}\text { D2 } \\
(\mathrm{mm})\end{array}$ & $\begin{array}{l}\text { D3 } \\
(\mathrm{mm})\end{array}$ & Mean \pm SD & \\
\hline PPI (1)" & 8 & 10 & 7 & $14.33 \pm 3.51^{\mathrm{DaE}}$ & \multirow{5}{*}{0.097} \\
\hline $\operatorname{MUV}(2)$ - & 15 & 10 & 9 & $15.33 \pm 2.08^{\mathrm{Da} \mathrm{E}}$ & \\
\hline $\mathrm{AHA}(3) \cdot$ & 20 & 18 & 19 & $7.33 \pm 1.53^{a x}$ & \\
\hline CONT (4) & 0 & 0 & 0 & $00 \pm 0$ & \\
\hline AMPIC (5) & 24 & 24 & 24 & $24 \pm 0$ & \\
\hline
\end{tabular}

PPI (1)=Alphitolic acid, MUV (2)=Epigouanic acid, AHA (3)=Methyl angolensate, CONT (4)=Rohituca-3, AMPI (5)=Sinensetin, D 1, 2 and 3: Diameter of inhibition measured, Avg: Average of three repetitions of inhibition diameter, SD: Standard Deviation, MIC: minimum inhibition concentration, $\mathbf{\square}: 200 \mu \mathrm{g} / \mathrm{mL}, \mathbf{~ : ~} 10 \mu \mathrm{g} /$ disc, oop <0.05) [compounds vs control], $(\mathrm{P}<0.01)$ [Compounds 1,1 and 3], the values marked with the letter $\mathrm{E}$ are not significantly different.

At a concentration of $25 \mathrm{mg} / \mathrm{mL}$ the compounds of PPI (1)=Alphitolic acid, MUV (2)=Epigouanic acid, AHA (3) $=$ Methyl angolensate, AMPI (5)=Sinensetin at $10 \mu \mathrm{g} / \mathrm{disc}$ have an effect significant on the Pseudomonas aeruginosa strain tested compared to the control. In the presence of the compounds of PPI (1)=Alphitolic acid $(\mathrm{P}<0.05)$, MUV (2)=Epigouanic acid (P <0.05) and AHA (3)=Methyl angolensate $(\mathrm{P}<0.05)$ Pseudomonas aeruginosa has developed diameters inhibition within 24 hours of 8.33, 11.33 and $19 \mathrm{~mm}$ respectively (Figure 4). A significant difference of the compound AHA $(3)=$ Methyl angolensate $(\mathrm{P}<0.01)$ compared to the compound PPI (1)=Alphitolic acid and MUV (2)=Epigouanic acid, on the other hand no significant difference between the compounds of (1)=PPI and MUV (2)=Epigouanic acid.

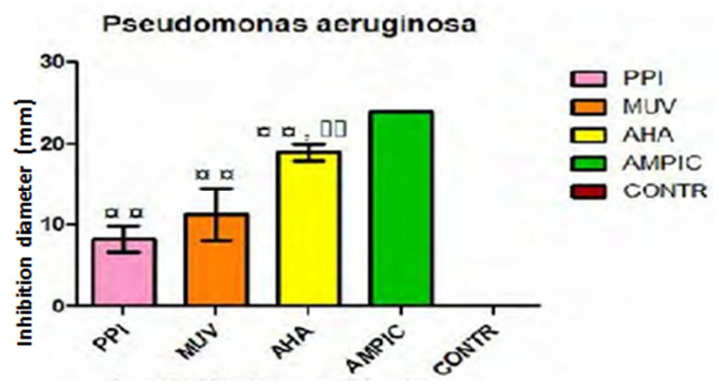

Figure 4. Antimicrobial activity of the compounds on Pseudomonas aeruginosa.

\subsubsection{Antibacterial Activity of the Compounds on Proteus vulgaris}

The different compounds were tested on Proteus vulgaris and the results are given in Table 5 below.

Table 5. Inhibitory effect of the compounds on the culture of Proteus vulgaris (expressed in diameter of inhibition of bacterial growth +/- standard deviation).

\begin{tabular}{|c|c|c|c|c|c|}
\hline \multirow[b]{2}{*}{ Compounds } & \multicolumn{4}{|c|}{ Proteus vulgaris } & \multirow{2}{*}{$\begin{array}{l}\text { CMI } \\
(\mathrm{mg} / \mathrm{mL})\end{array}$} \\
\hline & $\begin{array}{l}\text { D1 } \\
(\mathrm{mm})\end{array}$ & $\begin{array}{l}\text { D2 } \\
\text { (mm) }\end{array}$ & $\begin{array}{l}\text { D3 } \\
(\mathrm{mm})\end{array}$ & $\begin{array}{l}\text { Mean } \pm \\
\text { SD }\end{array}$ & \\
\hline PPI (1)" & 0 & 0 & 0 & $00 \pm 0^{\mathrm{v}}$ & \multirow{5}{*}{0.048} \\
\hline MUV (2) • & 9 & 11 & 10 & $10 \pm 1.00^{46}$ & \\
\hline $\mathrm{AHA} \mathrm{(3)} \mathrm{-}$ & 0 & 0 & 0 & $00 \pm 0^{\mathrm{v}}$ & \\
\hline CONT (4) & 0 & 0 & 0 & $00 \pm 0$ & \\
\hline AMPIC (5) & 25 & 25 & 25 & $25 \pm 0$ & \\
\hline
\end{tabular}

PPI (1)=AlphitoliC acid, MUV (2)=Epigouanic acid, AHA (3)=Methyl angolensate, CONT (4)=Rohituca-3, AMPI (5)=Sinensetin, D 1, 2 and 3: Diameter of inhibition measured, Avg: Average of three repetitions of inhibition diameter, SD: standard deviation, MIC: minimum inhibition concentration, $\mathbf{\square}: 200 \mu \mathrm{g} / \mathrm{mL}, \bullet: 10 \mu \mathrm{g} / \mathrm{disc}$, op $<0.05$ ) [compounds vs control], GG $(\mathrm{P}<0.01)$ [Compound 2, 1 and 3], the values marked with the letter $\mathrm{v}$ are not significantly different.

At a concentration of $25 \mathrm{mg} / \mathrm{mL}$ the compounds of MUV (2)=Epigouanic acid, AMPI (5)=Sinensetin at $10 \mu \mathrm{g} / \mathrm{disc}$ have a significant effect on the strain of Proteus vulgaris tested compared to the control, however no difference significant between the compounds of PPI (1)=Alphitolic acid and AHA (3)=Methyl angolensate compared to the control. In the presence of the compound MUV $(2)=$ Epigouanic acid $(\mathrm{P}<0.05)$ Proteus vulgaris developed diameters of inhibition within 24 hours of $10 \mathrm{~mm}$ (Figure 5). A significant difference of the MUV (2)=Epigouanic acid ( $P$ $<0.01)$ compared to the compounds PPI (1)=Alphitolic acid 
and AHA (3)=Methyl angolensate, on the other hand no significant difference between the compounds PPI $(1)=$ Alphitolic acid and AHA (3)=Methyl angolensate.

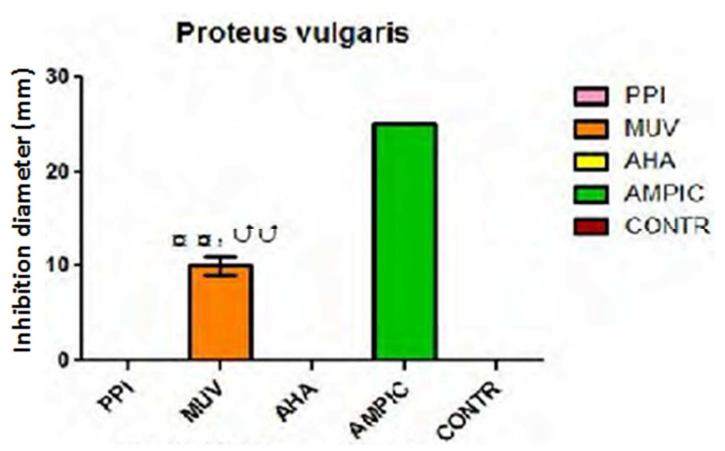

Figure 5. Antibacterial activity of the compounds on Proteus vulgaris.

\subsection{Discussion}

Antimicrobial substances are defined as substances used to destroy microorganisms or prevent their growth, including antibiotics and other antibacterial and antifungal agents. In fact, all the compounds reacted positively on at least one of the microbial strains tested. It is also noted that the compound (2) MUV is endowed with very appreciated antibacterial properties on 2 strains Staphylococcus aureus and Pseudomonas aeruginosa. In addition, compounds 1, 2 and 3 do not show any inhibitory activity of bacterial growth vis-à-vis Proteus vulgaris. In view of the previous results, we have shown that the compound (3) AHA shows a significant effect against Pseudomonas aeruginosa and the compound (2) MUV against Proteus vulgaris, Compounds 1, 2, 3 and 4 have a comparable effect between them concerning strains of Staphylococcus aureus and Escherichia coli. The efficacy of compound (3) AHA against Pseudomonas aeruginosa can be explained by the dominance of sesquiterpene lactones [52], in fact, bacteria are sensitive to this type of metabolite. For compound (2) MUV against Proteus vulgaris and Escherichia coli is probably due to the presence of terpenoids reported in this plant $[53,54]$.

The compound (5) AMPI against Escherichia coli is believed to have antibacterial properties against Gram positive and negative [55]. Kil et al. [56], Al-Habib et al. [57], Kumar et al. [58] and Souza et al. [59] reported that the antimicrobial activities of some plant extracts are due to the high quality of the phenolic compounds. Flavonoids have a very large and diverse antibacterial activity. Indeed, they attack a large number of bacteria with different intensity depending on the microorganism and the ecosystem in which it is found: flavonoids are able to inhibit the growth of different types of bacteria: Staphylococcus aureus [60], Escherichia coli [61]. The antimicrobial and therefore antiinfectious activity of flavonoids has been demonstrated by numerous studies. This activity is mainly due to the ability of these molecules to inhibit DNA expression and the synthesis of certain enzymes and membrane proteins in microorganisms [61]. This confirms the findings of Cushnie et al. [62] which states that each compound acts differently on microorganisms. That is to say, that a compound can have a very important action on one germ and less action, or even no action on another.

The solid-medium diffusion test is only a screening of the antimicrobial activities of the different compounds, it allows us to select for each strain the compound which has the most activity among all the natural compounds. It is also a preliminary test for another complementary microbiological test, which is the dilution in liquid medium to determine the MIC which could be determined or justified at 0.097 and 0.195 for the most sensitive strains of Escherichia coli and Pseudomonas aeruginosa. Shown in Tables 2, 3, 4 and 5, the results of the antibacterial susceptibility test to the compounds indicated that the average values are three measures. The bacteriostatic action results in the appearance of a zone of inhibition around the paper disc impregnated with the raw compounds studied. The diameter of the zone of inhibition differs from bacteria to bacteria and from compound to compound. As has been reported in the literature, we considered that a compound has a bacteriostatic action if its diameter of inhibition is greater than $12 \mathrm{~mm}$ [63]. The antibacterial activity of plant compounds is due to the different chemical functions present. In this plant, flavonoids and triterpenoids as well as other compounds of a phenolic nature which are classified as very active antibiotic compounds $[64,65]$. Furthermore, our results therefore show a great variability in the bacteriostatic qualities of the compounds with respect to the different strains. Grampositive strains of Staphylococcus aureus are more sensitive than other bacterial strains tested as Gram-negative. The resistance of the latter is not surprising, in fact, these bacteria have an intrinsic resistance to biocidal agents which is related to the nature of their outer membranes composed of lipopolysaccharides which form an impermeable barrier to hydrophobic compounds. In the presence of agents permeabilizing the outer membrane, substances inactive against these bacteria become active.

\section{Conclusion}

Natural substances are increasingly important in therapy. Indeed, medicinal plants are real chemical factories from which an advantage must be obtained. This study focused on the evaluation of the antibacterial activities of secondary metabolites isolated from the roots of Khaya senegalensis and their inhibitory effect in vitro. An antibiogram was carried out to study the rendering of resistance enzymes. The antibiogram made it possible to establish the sensitivity profile of the strains tested with regard to certain antibiotics. The antibacterial potentialities of the various compounds were evaluated by the method of diffusion in solid medium and in liquid medium. In view of the results obtained on the compounds, we have shown that the compound (3) shows a significant effect against Pseudomonas aeruginosa, Compounds 1, 2, 3 and 4 have a comparable effect between them concerning the strains of Staphylococcus aureus and Escherichia coli. The antibacterial activity of the various 
compounds on solid agar medium shows little or no effect. There would therefore be a synergy of action at the level of the chemical principles present in the compounds. However, compounds 1, 3 and 5 have shown an inhibitory effect against these germs (resistance enzymes). The antibacterial properties of the roots of Khaya senegalensis highlighted in this work would explain the uses of this plant in traditional medicine for the treatment of infectious diseases.

\section{Acknowledgements}

The authors are grateful, Dr Froumsia Moskia from the Department of Biological Sciences, Faculty of Science, University of Maroua for identification of Khaya senegalensis Roots and Mr. Mamoudou Hamadou, from the Laboratory of Phytobiochemistry and Medicinal Plant, Department of Biological Sciences, Faculty of Science, University of Maroua for Antimicrobial tests.

\section{Conflicts of Interest}

The authors declare that they have no competing interests.

\section{References}

[1] Paterson, D. L., Doi, Y. (2017). Enterobacteriaceae. Springer International Publishing AG 2017. D. L. Mayers et al. (eds.), Antimicrobial Drug Resistance. DOI: 10.1007/978-3-31947266-9_8.

[2] Talaro, K. P., and Chess, B. (2018). Chapter 20: The GramNegative Bacilli of Medical Importance in Foundations in Microbiology, Tenth Edition. Mc Graw Hill Education: 947p.

[3] Armbruster, C. E., Mobley, H. L, T., and Pearson, M. M. (2018). Pathogenesis of Proteus mirabilis infection. American Society for Microbiology: 73p. DOI: 10.1128/ecosalplus.ESP0009-2017.

[4] OMS. (2014). Premier rapport de l'OMS sur la résistance aux antibiotiques: une menace grave d'ampleur mondiale. OMS, Organisation Mondiale de la Santé, 20 avenue Appia, 1211 Genève 27 (Suisse). 6p.

[5] CDC. (2013). Antibiotic Resistance Threats in the United States, 2013. U. S. Department of Health and Human Services. Centers for Disease Control and Prevention; 113p. DOI: http://dx.doi.org/10.15620/cdc:82532.

[6] Adams, R. J., Kim, S. S., Mollenkop, D. F., Mathys, D. A., Schuenemann, G. M., Daniels, J. B., and Wirrum, T. E. (2018). Antimicrobial-resistance Enterobacteriaceae recovered from companion animal and lifestock environments. Zoonoses Public Health, 00: 1-9. DOI: 10.1111/zph.12462.

[7] Armand-Lefèvre, L., Andremont, A., Ruppé, A. (2018). Travel and acquisition of multidrug- resistant. Enterobacteriaceae. Médecine et Maladies Infectieuses. DOI: 10.1016/j.medmal.2018.02.005.

[8] Bliven, K., Lampel, K, A. (2017). Chapter 6: Shigella In: Foodborne Diseases, third edition edited by Christine E. R. Dodd, Tim Aldsworth, Richard A. Stein, Dean O. Cliver, Hans P. Riemann. Elsevier Academic Press: 171-188.
[9] Madec, J. Y., Haenni, M., Jouy, E., Granier, S., Weil, F. X, Hello, S. L. (2012). Les Entérobactéries résistantes aux céphalosporines de dernières générations: de l'animal à l'Homme. Bulletin épidémiologique, santé animale et alimentation n53/Spécial Antibiotiques et Antibiorésistances: 37-39.

[10] Carle, S. (2009). La résistance aux antibiotiques: un enjeu de santé publique important. Pharmactuel, 42 (2): 6-21.

[11] Li, X., Nie, C., Zhang, Z., Wang, Q., Shao, P., Zhao, Q., Chen, Y., Wang, D., Li, Y., Jiao, W., Li, L., Qin, S., He, L., Jia, Y., Ning, Z., Qu, L. (2017). Evaluation of genetic resistance to Salmonella Pullorum in three chicken lines. Poultry Science, 97 (3): 764-769. DOI: $10.3382 / \mathrm{ps} / \mathrm{pex} 354$.

[12] MSF. (2018). Bulletin d'information Mars-Avril 2018. Médecins Sans Frontières, MSF Suisse-Mission Cameroun, Bureau situé $300 \mathrm{~m}$ pares ELECAM, Rue 1.828-Bastos, Yaoundé: $4 \mathrm{p}$.

[13] Akova, M., Daikos, G. L., Tzouvelekis, L., Carmeli, Y. (2012). Interventional strategies and current clinical experience with carbapenemase producing Gram-negative bacteria. Clinical Microbiology and Infection, (18): 439-448. DOI: 10.1111/j.1469-0691.2012.03823.x.

[14] OMS. (2018a). Infections à Salmonella (non typhiques). OMS, Organisation Mondiale de la Santé, 20 avenue Appia, 1211 Genève 27 (Suisse): $6 \mathrm{p}$.

[15] Awouafack, M. D., McGaw, L.., Gottfried, S. et al. (2013). Antimicrobial activity and cytotoxicity of the ethanol extract, fractions and eight compounds isolated from Eriosema robustum (Fabaceae). BMC Complement Altern Med, 13: 289. DOI: 10.1186/1472-6882-13-289.

[16] Cowan, M. M. (1999). Plant products as antimicrobial agents. Clin. Microbiol. Rev, 12: 564-582. DOI: 10.1128/CMR.12.4.564.

[17] Parekh, J., Chanda, S. (2007). In vitro antibacterial activity of crude methanol extract of Woodfordia fruticosa Kurz flower (Lythacease). Braz. J. Microbiol, 38: 2. DOI: 10.1590/S151783822007000200004 .

[18] Clardy J., Walsh C. (2004). Lessons from natural molecules. Nature, 432: 829-837. DOI: 10.1038/nature03194.

[19] Verpoorte, R., Choi Y. H., Kim H. K., (2005). Ethanopharmacology and system biology: a perfect holistic match. J Ethnopharmacol, 100: 53-56. DOI: 10.1016/j.jep.2005.05.033.

[20] Abiodun, F and Osahon, O. (2009). Phytochemical screening and evaluation of stem bark extract of Khaya senegalensis (Meliaceae) on methicillin resistant Staphyloccocus aureus. Canadian Journal of Pure and Applied Sciences, 3 (3): 925-928.

[21] Tao, Y., Chuan-Rui, Z, Sheng-Ping, Y., and Jian-Min, Y. (2010). Limonoids and Triterpenoids from Khaya senegalensis, J. Nat. Prod, 73 (4): 669-674. DOI: 10.1021/np1000158.

[22] Sokpon, N., et Ouinsavi, C. (2004). Gestion des plantations de Khaya senegalensis au Bénin. Bois et forêts des tropiques, 279 (1): 37-46.

[23] El-Tahir, A., Ibrahim, A. M, Satti, G. M. H, Theander, T. G., Kharazmi, A. and Khalid, S. A. (1998). The potential antileishmanial activity of some Sudanese medicinal plants. Phytother Res, 12: 576-579. DOI: 10.1002/(SICI)10991573(199812)12:8<576::AID-PTR354>3.0.CO;2-\#. 
[24] Kone, W. M., Atindehou, K. K., Terreaux, C., Hostettmann, K., Traore, D. et Dosso, M. (2004). Traditional medicine in North Côte-d'Ivoire: screening of 50 medicinal plants for antibacterial activity. Journal of Ethnopharmacology, 93: 4349. DOI: 10.1016/j.jep.2004.03.006.

[25] Stephen, U. A., Abiodun, F., Osahon, O. and Ewaen, E. (2009). Phytochemical Analysis and Antibacterial Activity of Khaya grandifoliola Stem Bark. Journal of Biological Sciences, 9: 63-67. DOI: 10.3923/jbs.2009.63.67.

[26] Kerharo J. et Adam G. (1974). La pharmacopée sénégalaise traditionnelle: plantes Médicinales et toxiques. Ed Vigot frères Paris ISBN 2-7114 Ŕ 0646-6.

[27] Fagbohoun, L., Gbaguidi, A, F., Ayedoun, A. A., Moudachirou Mansourou, M. C et Vieillescazes, C. (2014). Etudes ethnobotanique et Phytochimique des plantes tinctoriales sources de colorants naturels et matériaux résineux traditionnels du Bénin dans le domaine artisanal (Ifangni/Bénin) $S F E$ in Press.

[28] Khalid, S. A., Friedrichsen, G. M., Kharazmi, A., Theander, T. G., Olsen, C. E. And Christensen, S. B. (1998). Limonoids from Khaya senegalensis. Phytochemistry, 49 (6): 1769-1772. DOI: $10.1016 / \mathrm{s} 0031-9422(98) 00284-2$.

[29] Comité de l'Antibiogramme de la société Française de Microbiologie (CA-SFM). (2017). Communiqué du comité de l'antibiogramme de la société Française de microbiologie. Société Française de Microbiologie, Institut Pasteur-Paris: $127 \mathrm{p}$.

[30] Kiehlbauch, J. A., Hannett, G. E., Salfinger, M., Archinal, W., Monserrat, C., Carlyn, C. (2000). Use of the National Committee for Clinical Laboratory Standards guidelines for disk diffusion susceptibility testing in New York state laboratories. J Clin Microbiol, 38 (9): 3341-3348. DOI: 10.1128/JCM.38.9.3341-3348.2000

[31] Olsson-Liljequist, B., Larsson, P., Walder, M, Miörner, H. (1997). Antimicrobial susceptibility testing in Sweden. III. Methodology for susceptibility testing. Scand J Infect Dis Suppl, 105: 13-23.

[32] Ananil, K., Hudson. J. B., Souzal, C., Akpaganal. K. Towe, G. H. N., Amason, J. T. and Gbeassor. (2000). Investigation of medicinal plants of TOGO for antiviral and antimicrobial activities. Phannaceutical Biology, 38 (1): 40-45. DOI: 10.1076/1388-0209(200001)3811-BFT040.

[33] NCCLS. (2002). Performance standards for antimicrobial disk susceptibilty testing. $12^{\text {th }}$ informational supplement. NCCLS document, M100-S12. National Committee for clinical Laboratory Standards, Wayne, Pa.

[34] Rahal, J. J. (2006). Novel Antibiotic Combinations against Infections with Almost Completely Resistant Pseudomonas aeruginosa and Acinetobacter Species. Clinical Infectious Diseases, 43 (2): S95-S99. DOI: 10.1086/504486.

[35] NCCLS. (1999). Methods for determining bactericidal activity of antimicrobial agents. Approved guideline, M26-A. National Committee for Clinical Laboratory Standards, Wayne, Pa.

[36] Gossan, D. P, Alabdul Magid, A, Yao-Kouassi, P. A, et al. (2017). Triterpene glycosides from the aerial parts of Gouania longipetala. Phytochemistry, 134: 71-77. DOI: 10.1016/j.phytochem.2016.11.004.

[37] Giacomelli, S. R., Maldaner, G., Stuker, C., Marasciulo, C.,
Schmidt, J. (2007). Triterpenoids from Gouania ulmifolia. Planta Med, 73: 499-501. DOI: 10.1055/s-2007-967166.

[38] Leal, I. C., dos Santos, K. R., Júnior II, et al. (2010). Ceanothane and lupane type triterpenes from Zizyphus joazeiro-An Anti-staphylococcal evaluation. Planta Med, 76 (1): 47-52. DOI: $10.1055 / \mathrm{s}-0029-1185947$.

[39] Chouna, J. R., Nardella, F., Lenta, B. N. et al. (2016). Ceanothane-type triterpenoids from Cyphostemma adenocaule. Arch. Pharm. Res. DOI: 10.1007/s12272-016-0801-1.

[40] Bouopda, S. P., Tamo, S. H., Riwom. E. Ndogo Eteme, O., Mundene, T. J. L., Avina Ze, J. M., et al. (2019). Effects on the phagocytosis modulation of stems extract and triterpenes from Gouania longipetala (Hemsl.), a plant of the Cameroonian pharmacopeia. J. Nat. Prod. Resour, 5 (1): 199-203. DOI: 10.30799/jnpr.073.19050101.

[41] Miguita, C. H., Sarmento, U. C., Hamerski, L., Garcez, W. S., Garcez, F. R. Mexicanolide- and Andirobine-type limonoids from the fruits of Guarea kunthiana. Rec. Nat. Prod.2014, 8 (3): 290-293. DOI: 10.3390/molecules20010111.

[42] Abdelgaleil1, S. A. M., Nakatani, M. (2003). Antifeeding activity of limonoids from Khaya senegalensis (Meliaceae). J. Appl. Ent, 127: 236-239. DOI: 10.1046/j.14390418.2003.00742.x.

[43] Mulholland, D., Taylor, D. (1980). Limonoids from the seeds of the natal mahogany, Trichilia dregeana. Phytochemistry, 19: 2421-2425. DOI: 10.1016/S0031-9422(00)91040-9.

[44] Gunatilaka, A., Bolzani, V., Dagne, E., Hofmann, G., Johnson, R., McCabe, F., Mattern, M. and Kingston, D. (1998). Limonoids Showing Selective Toxicity to DNA Repair Deficient Yeast and Other Constituents of Trichilia emetica, Journal of Natural Products, 61: 179-184. DOI: $10.1021 / \mathrm{np} 9701687$.

[45] Junges, M. J., Jaao, B. T., Vierra, P. C. (1999). The use of ${ }^{13} \mathrm{C}$ and ${ }^{1} \mathrm{H}$ NMR in the structural elucidation of a new nor-lupane triterpènes. J. Braz. Chem. Soc, 10: 317-320. DOI: 10.1590/S0103-50531999000400011.

[46] Duan, L., Dou, L., Yu, K., Guo, L., Bai-Zhong, C., Li, P., Liu, E. (2017). Polymethoxyflavones in peel of Citrus reticulata 'Chachi' and their biological activities. Food Chem, 234: 254261. DOI: 10.1016/j.foodchem.2017.05.018.

[47] Zhenqing Li., Ziyan Zhao., Zhiqin Zhou. (2018). Simultaneous Separation and Purification of Five Polymethoxylated Flavones from "Dahongpao" Tangerine (Citrus tangerina Tanaka) Using Macroporous Adsorptive Resins Combined with Prep-HPLC. Molecules, 23: 2660. DOI: $10.3390 /$ molecules23102660.

[48] Walsh, C. (2003). Section III: Antibiotic resistance In: Antibiotics: actions, origins, resistance. American Society for Microbiology (ASM) Press: 89-155.

[49] Bidet, P., and Bingen, E. (2011). Chapitre 34.2: Enterobacteriaceae (à l'exception du genre Yersinia): in Bactériologie Médicale Techniques usuelles by François Denis, Marie-Cécile Ploy, Christian Martin, Édouard Bingen and Roland Quentin. Elsevier Masson: 631p.

[50] OMS. (2018b). Antimicrobial resistance. OMS, Organisation Mondiale de la Santé, 20 avenue Appia, 1211 Genève 27 (Suisse). 
[51] Hasnain, A., Nasim, W., Mubarak, H., Mirza, N., Khan, S., Su, X., Ahmed, S., and Hashmi, M, Z. (2017). Chapter 2: Antibiotics resistance genes in Antibiotics and Antibiotics resistance genes in soils: monitoring, toxicity, risk assessment and management by Hashmi, M, Z., Strezok, V., and Varma, A. Springer International Publishing, 51: 19-38. DOI https://doi.org/10.1007/978-3-319-66260-2_2.

[52] Laid, M. M. E. F., Hegazy and Ahmed, A. A. (2008). Sesquiterpene lactones from Algerian Artemisia herbaalba, Phytochemistry Lett, 1: 85-88. DOI: 10.1016/j.phytol.2008.04.002.

[53] Atto V, Koffi, D. P., Monteomo. G. F., Adeoti, M. F. (2016). Phytochemical Screening of Sclerocarya birrea (Anacardiaceae) and Khaya senegalensis (Meliaceae) Antidiabetic Plants. Int. J. Pharm. Chem, 2 (1): 1-5. DOI: 10.11648/j.ijpc.201602 01.11.

[54] Shan, B., Cai, Y. Z., Brooks, J. D., Corke, H. (2007). The in vitro antibacterial activity of dietary spice and medicinal herb extracts". International J Food Microbiology, 117: 112-119. DOI: $10.1016 / j . i j f o o d m i c r o .2007 .03 .003$.

[55] Mariana, R., Houde, R., Tatjana Stevanovic, M. Sci., ing. (2010). Département des sciences du bois et de la forêt, CRB, Université Laval Potentiel de Développement lié aux extractibles: État des connaissances et revue des marchés.

[56] Kil, H. Y., Seong, E. S., Ghimire, B. K., Chung, I. M., Kwon, S. S et al. (2009). Antioxidant and antimicrobial activities of crude sorghum extract, Food Chem, 115: 1234-1239. DOI: 10.1016/j.foodchem.2009.01.032.

[57] AL-Habib, A., AL-Saleh, E., Safer, A., Afzal, M. (2010). Bactericidal effects of grape seed extracts on methicillin resistant Staphylococcus aureus (MRSA), J. Toxicol. Sci, 35: 357-364. DOI: $10.2131 /$ jts.35.357.

[58] Kumar, K. A., Narayani, M., Subanthini, A., Jayakumar, M. (2011). Antimicrobial activity and phytochemical analysis of citrus fruit peels-utilization of fruit waste. Int. J. Eng. Sci. Tech, 3: 5414-5421.

[59] Souza, J. G., Toledo, A. G., Santana, C. B., Santos, C. V., Mallmann, A. P et al. (2017). Chemical composition and antibacterial activity of essential oil and leaf extracts of Zanthoxylum caribaeum Lam. against serotypes of Salmonella, Rev. Bras. Saude Prod. Anim. Salvador, 18: 446453. DOI: 10.1590/s1519-99402017000300005.

[60] Babayi, H., Kolo, I, Okogum, J. I. (2004). The antimicrobial activities of methanolic extracts of Eucalyptus camaldulensis and Terminalia catappa against some pathogenic microorganisms. Biochemistry, 16 (2): 102-5. DOI: 10.4314/biokem.v16i2.32578.

[61] Ulanowska, K. (2006). Differential antibacterial activity of genistein arising from global inhibition of DNA, RNA and protein synthesis in some bacterial strains. Arch. Microbial, 184 (5): 271-8. DOI: $10.1007 / \mathrm{s} 00203-005-0063-7$.

[62] Cushnie, T. P, Hamilthoh, V. E. S, Lamb, A. J. (2003). Assessement of the antimicrobial activity of selected flavonoids and consideration of discrepancies between previous reports. Microbiol Res, 158 (4): 281-9. DOI: 10.1078/0944-5013-00206.

[63] Sagdiç O. (2003). Sensitivity of four pathogenic bacteria to Turkish thyme and oregano hydrosols. Lebensm-Wiss. U.Technol, 36: 467-473. DOI: 10.1016/S0023-6438(03)00037-9.

[64] Rojas, A., Hernandez, L., Pereda-Miranda, R., Mata, R. (1992). Screening for antimicrobial activity of crude drug extracts and pure natural products from Mexican medicinal plants. J. Ethnopharmacology, 35: 275-283. DOI: 10.1016/0378-8741(92)90025-M.

[65] Marjorie, M. C. (1999). Plant Products as Antimicrobial Agents. Clinical Microbiology Reviews, 564-582. DOI: 10.1128/CMR.12.4.564. 